\title{
В.П. Москвин
}

\section{ДВУСМЫСЛЕННОСТЬ РЕЧИ: СТИЛИСТИЧЕСКИЙ АСПЕКТ}

Уточняется состав и систематизируются фигуры двусмысленной речи. Анализ показывал, что: 1) двусмысленность представляет собой подразумевание единиць $A_{2}$ $\left(A_{3}, \ldots\right)$ под единицей $A_{1}$ адресантом при затрудненности выбора между $A_{1}$ и $A_{2}\left(A_{3}, \ldots\right)$ адресатом ввиду дефектности контекста; 2) условием речевой реализации категории двусмысленности является наличие ассочиативной связи между $A_{1}$ и $A_{2}$, возникающей при отношения: а) семантической производности « $A_{2}<A_{1} »$; б) тождества формы « $A_{2}=A_{1} » ;$ в) близкозвучия " $A_{2} \approx A_{1} »$. Отночению (а) отвечают таксономический перенос, метонимия и незамкнутая метафора, отномению (б) - дилогия, отношению (в) - фонетическая аллюзия.

Ключевые слова: двусмысленность, фигура речи, паксономический перенос, метонимия, незамкнутая метафора, аллегория, дилогия, фонетическая аллюзия.

\section{Введение}

Категорию двусмысленности принято ставить в таксономическое соотношение прежде всего с такими понятиями, как однозначность, многозначность, полисемия и неоднозначность. Рассматривая данные понятия в рамках дихотомии «язык / речь», Анна А. Зализняк [1. С. 20] относит полисемию к области языковых противопоставлений, неоднозначность и двусмысленность - к речевой сфере, многозначность же расценивает как более широкое по сравнению с предыдущими тремя ${ }^{1}$. Трактовка многозначности как понятия, принадлежащего не только языку, но и речи, адекватно отражает:

1. Терминологический узус, однако те (немногие) авторы, которые применяют понятие 'контекстуальная многозначность', зачастую подразумевают, судя по приводимым примерам, иные феномены, в частности:

1.1. Взаимодействие: а) значения и коннотации; б) значения и внутренней формы, ср.: «Многозначно также название пьесы - “Крошка Алиса". Первоначально оно ассоциируется с именем героини пьесы - мисс Алисы, но затем эта связь оказывается ложной, поверхностной». Далее следуют интерпретации: а) «Более глубокой представляется попытка критиков провести параллель между названием пьесы Олби и названиями произведений Льюиса Кэрролла “Алиса в стране чудес” и “Алиса в Зазеркалье”»; б) «Го-

${ }^{1}$ Применительно к случаям двусмысленности Анна А. Зализняк предпочитает использовать оценочно не отмеченный термин неоднозначность, указывая на обсценную сторону выражений двусмысленная шутка, говорить двусмысленности: «...“второй смысл” часто бывает в той или иной степени “неприличным”» [1. С. 25]. 
раздо более правомочным представляется, однако, толкование названия, исходя из этимологии имени “Алиса", которое по-древнегречески означает “истина"1» [2. С. 66-67]. Интерпретация (а) связана с интертекстуальной коннотацией, (б) - с этимологической внутренней формой слова.

1.2. Взаимодействие двух смыслов, т. е. двусмысленность:

(1) Какую выдержку надо иметь, чтобы сфотографировать тебя! («Выдержска. 1. Терпение. 2. Время экспонирования в фотографии. Актуализированы сразу оба значения») [3. С. 137].

1.3. Лексическую полисемию [4], etc.

Такое несоответствие примеров термину или дефиниции встречаем и в литературе прошлых лет. Так, в Лексиконе Суды (X в.) читаем:

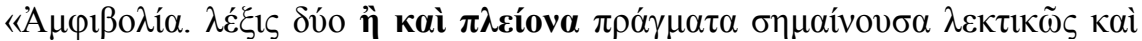

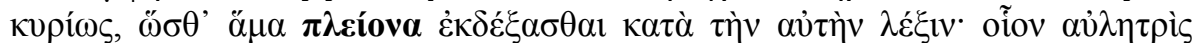

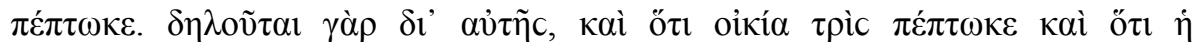

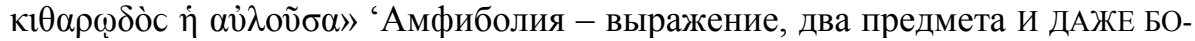
ЛЕЕ обозначающее, красноречиво и подлинно, так что одновременно НЕСКОЛькО <предметов> подразумевается в одном и том же выражении.

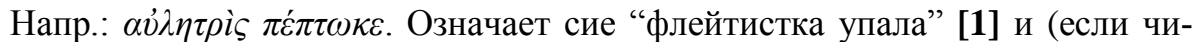

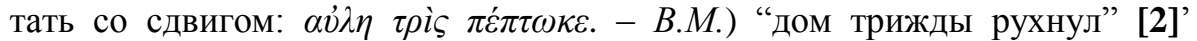

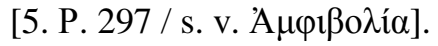

2. Речевые реалии. Необходимо отметить, что речевая единица редко бывает способна нести в одном и том же контексте одновременно более двух смыслов ${ }^{2}$. Видимо, в силу этого обстоятельства применительно к речи принято, начиная с Античности, говорить именно о двусмысленности,

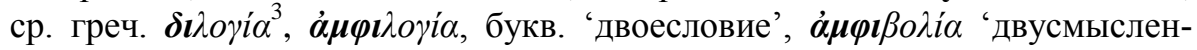
ность', лат. sermonis ambiguitas 'двусмысленность речи', sensus dubius 'двойной смысл', греч. $\delta \boldsymbol{i} \lambda o \gamma o \varsigma, \boldsymbol{\delta} \boldsymbol{i} \gamma \lambda \omega \sigma \sigma o \varsigma$, лат. bilinguis 'двуличный', букв. 'двоеречивый':

(2) quippe domum timet ambiguam Tyriosque bilingues 'всех ведь страшит финикийцев двуличных двусловье’ [Virg., Aen. I: 661 (I в. до н. э.)].

Данный факт издавна получает отражение в дефинициях указанных

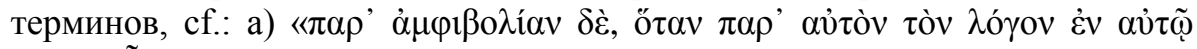

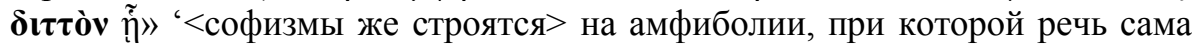

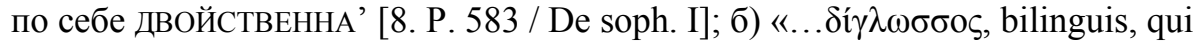
duplex et inconstans est in dictis, alia ore promit et alia pectore premit...»

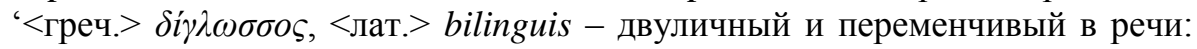

\footnotetext{
1 Здесь можно говорить лишь о приблизительном созвучии, ср. греч. $\dot{\alpha} \lambda \dot{\eta} \theta \varepsilon \imath \alpha$ 'истина', в эразмовом произношении: [alé:t(h)eja]. Этимология имени Алиса, как известно, спорна.

2 Так, из всех фигур, описанных ниже, многозначной бывает лишь незамкнутая метафора (см. раздел 1.3).

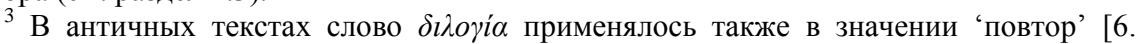
P. 464]; позже, как термин риторики, - и в более узком значении 'антанаклаза' (vide, e.g.: [7. P. 584]).
} 
ОДНО устами льстиво вещает, ИНОЕ в груди скрывает ${ }^{1}$ [6. Р. 464 / s. v.

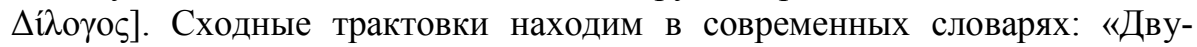
смысленный <...>. 1. Имеющий двОякий смысл, допускающий дВОЯкОЕ толкование» [9. С. 80].

При определении числа контекстуально взаимодействующих смыслов целесообразно различать понятия ‘авторский смысл / замысел’ (1) и ‘вариант интерпретации’ (2); ясно, что интерпретаций речевой единицы, в частности более или менее вольных, может быть практически необозримое множество. В монографии У. Эмпсона сближение понятий (1) и (2) дает такое понимание двусмысленности, при котором «...любое прозаическое утверждение может быть названо двусмысленным» (как пример приводится фраза The cat sat on the mat 'Кот сидел на ковре'); при этом «[и]нтерпретация <...> может проводиться в любом направлении, в котором пожелает интерпретатор...» [10. Р. 1] $]^{2}$. Данная трактовка представляется неоправданно широкой. М. Блэк, указывая на приверженность У. Эмпсона принципу, согласно которому слова имеют лишь смысл, придаваемый интерпретатором («adherence to the Humpty-Dumpty principle» ${ }^{3}$ ), отмечает, что благодаря его книге понятие двусмысленности стало популярным, но вместе с тем «...претерпело девальвацию до точки бесполезности» [12. Р. 90].

Как качество речи двусмысленность соотносится со сферой линейноречевой, а значит, контекстуально релевантной. Считается, что контекст нарочито двусмысленной единицы, в частности каламбурной, должен поддерживать неоднозначность ее интерпретации: «Контекст каламбура, вместо того, чтобы быть нацеленным на подавление потенциальной двусмысленности, сознательно строится таким образом, чтобы усилить двусмысленность, с тем чтобы сделать невозможным выбор между значениями и тем самым оставить читателя или слушателя В БЕСКОНЕЧНОМ МЕРЦАНИИ семантического пространства» [13. Р. 190]; ср.: а) «Мы называем двусмысленным - или содержащим двусмысленность - любой речевой образец, который может быть обоснованно переупорядочен двумя (или более) способами, представленными в виде различных прозаических утверждений, НИ ОДНО ИЗ КОТОРЫХ НЕ МОЖЕТ БЫТЬ ПОЛНОСТЬЮ ПОДТВЕРЖДЕНО ИЛИ ПОЛнОстьЮ СНЯТО синтаксисом или контекстом» [14. Р. 40]; б) «...для создания двусмысленности необходим специфический контекст...» [15. C. 25]. Как именно строится такой контекст, не уточняется.

Если полагать, что средствами контекста может быть устранен любой тип двусмысленности, то основной ее причиной следует считать выявленную римским ритором Фортунацианом (IV-V в.) «ambiguitas per

\footnotetext{
${ }^{1}$ Обратим внимание на бинарное противопоставление выраженного и подразумеваемого смыслов, остроумно подчеркнутое созвучием (ore / pectore) и парехезой: promit / premit.

2 Этот же подход находим в работе А. Осса-Ричардсона [11. Р. 1-2].

${ }^{3} \mathrm{Cp} .:-$ Когда я беру слово, оно означает то, что я хочу, не больше и не меньше, сказал Шалтай (= Humpty-Dumpty. - В.M.) презрительно [Л. Кэрролл. Алиса в Зазеркалье, гл. VI. Пер. Н.М. Демуровой].
} 
deficientiam» - двусмысленность, источником которой выступает неполнота контекста [16. P. 100 / Art. rhet. I, 24]. В таком случае под ДВУСМЫСЛЕННОСТьЮ необходимо понимать подразумевание адресантом единицы $\mathbf{A}_{2}$ $\left(A_{3}, \ldots\right)$ под речевой единицей $A_{1}$ при невозможности уверенного выбора « $\mathbf{A}_{1} \vee \mathbf{A}_{2}\left(\mathbf{A}_{3}, \ldots\right){ }^{1}$ для адресата ввиду дефектности контекста, напр.: мост $_{1}$ 'сооружение, возведённое над водным препятствием' $\vee$ мост $_{2}$ 'сон' V мост $_{3}$ 'память' $\vee$ мост $_{4}$ 'мечта'? (см. пример 22), ми $_{1}$ 'числительное' $\mathrm{V}$ mри 'повел. от тереть'? (см. пример 31), кутерьма 1 'суматоха' $\vee$ кутерь$\mathrm{Ma}_{2}$ 'тюрьма'? (см. пример 40) ${ }^{2}$ и т.д. Двусмысленность, т.е. возможность инотолкования речи, затрудненность выбора между единицами « $\mathrm{A}_{1} \vee \mathrm{A}_{2} \mathrm{~V}$ ...», предполагает не только отсутствие опорного контекста, но и ассоциативную связь между $\mathbf{A}_{1}$ и $\mathbf{A}_{2}$ (поскольку $\mathrm{A}_{1}$ имплицирует $\mathrm{A}_{2}$ ). Такая связь возникает, если данные единицы находятся в отношениях: 1) семантической производности « $\mathrm{A}_{2}<\mathrm{A}_{1} »$ (см. раздел 1$) ; 2$ ) полного тождества формы « $\mathrm{A}_{1}=\mathrm{A}_{2} »$ (см. раздел 2); 3) неполного тождества формы, т.е. созвучия или близкозвучия « $\mathrm{A}_{1} \approx \mathrm{A}_{2}$ » (см. раздел 3 ). Предложенному определению не будут соответствовать, в частности, следующие средства, трактуемые в научной литературе как двусмысленные:

1. Любой перенос, поддержанный контекстом, например замкнутая метафора. Так, У. Эмпсон [10. Р. 25] среди средств выражения двусмысленности называет метафору (без уточнения контекстуального типа) и как пример приводит глагол devour в следующем контексте:

(3) Beauty is but a flower // Which WRINKLES will devour (Th. Nash. Adieu, farewell earth's bliss...) 'Красота - не более чем цветок, // Который МОРщИНы съедят' [Т. Нэш. Прости, прощай, земное счастье... (XVI в.)].

Здесь, однако, возможность инотолкования ( $\mathrm{A}_{1}$ 'употребить в пищу' вм. $\mathrm{A}_{2}$ 'уничтожить') снимается контекстом. В этой связи кажется слишком широким предложенное У. Эмпсоном определение двусмысленности как «...любого словесного нюанса, даже незначительного, который дает пространство для альтернативных реакций на одну языковую единицу» [10. P. 1]. Данное определение не дает возможности развести: 1) реакции на взаимодействие, с одной стороны, двух смыслов, с другой - смысла и внутренней формы; 2) языковую полисемию и речевую однозначность номинативной единицы.

2. АНТАНАКЛАЗА [греч. $\dot{\alpha} v \tau \alpha v \alpha ́ k \lambda \alpha \sigma l \varsigma$ 'отражение'] - повтор слова в разных значениях. Ее основой служат: а) многозначное слово (см. пример 4а); б) омонимы (пример 4б):

\footnotetext{
${ }^{1}$ Здесь и далее используется принятый в логике символ дизъюнкции $\vee$ ‘или’ (от лат. vel 'или').

${ }^{2}$ Сфера действия основанных на дефектном контексте выражений ограничена: так, они неуместны в публичном дискурсе; еще Квинтилиан порицал неясность речений, имеющих два смысла, 'очевидного и скрывающегося за ним тайного': «Pessima vero sunt $\alpha \dot{\delta} \_\alpha v o ́ \eta \tau \alpha$, hoc est, quae verbis aperta occultos sensus habent...» [17. P. 50 / Inst. orat. VIII, 2: 20], ср. греч. plur. nom. $\dot{\alpha} \delta l \alpha v o ́ \eta \tau \alpha$, букв. 'неясности'.
} 
(4) а. Наполняются до края те края, что без // краев [А. Радашкевич. Памяти Жени (2014)].

б. Уходит Даль куда-то в даль... // Не затеряться бы в дали. // Немаловажная деталь: // вы все же Даль, а не Дали [В. Гафт. О. Далю (1981)].

Полисемант (4a) либо слово, имеющее омонимы (4б), в каждом случае речевого предъявления получает опорный контекст, обеспечивающий однозначную интерпретацию и исключающий возможность инотолкования (в противном случае прием не будет успешен): Наполняются до края $\left[\mathrm{A}_{1}\right.$

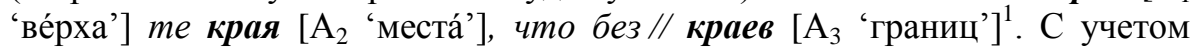
данного факта не выглядят обоснованными: а) отнесение антанаклазы к числу средств выражения двусмысленности [20. Р. 29, 30; 21. Р. 19-20; 22. Р. 168; 15. С. 87-90]; б) следующая трактовка двусмысленности, вступающая в конфликт с традицией определения этой категории: «...двусмысленность - это лингвистический феномен, заключающийся в наличии у высказывания или его фрагмента нескольких смыслов, проявляющихся одновременно или последовательно, обусловленное сочетанием языковых/речевых механизмов порождения двусмысленности с особым контекстом» [15. Р. 26]. Применительно к двусмысленности представляется более точным говорить о «мерцании семантического пространства» [13. С. 190], об «одновременном употреблении слова в двух разных смыслах» [23. Р. 134], т.е. о дизъюнкции « $\mathrm{A}_{1} \vee \mathrm{A}_{2} »$, но не конъюнкции « $\mathrm{A}_{1} \wedge \mathrm{A}_{2} »$.

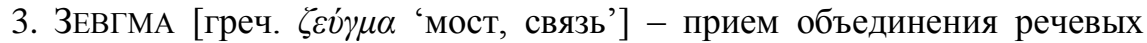
единиц общим компонентом. Специфика зевгмы проясняется в сравнении с гипозевксисом, который еще античные ученые считали фигурой, противоположной зевгме ${ }^{2}$ [24. Р. 301], и трактовали как лексико-синтаксический параллелизм. Грамматик IV в. Диомед [25. Р. 111], рассматривая эти фигуры, приводит такой пример гипозевксиса:

(5) Regem adit, et regi memorat nomenque genusque 'Пред царем он предстал, и царю он назвал имя и род свой’ [Virg., Aen. X: 149].

Сопоставление данных приемов приводит к следующим выводам: а) зевгма устраняет лексико-синтаксический параллелизм, представляя собой «экономию параллелизма» [26. Р. 177], если же мы «...распространим зевгму, то получим параллельные конструкции, изоколон» [27. С. 68]; б) обе фигуры объединены отношениями взаимной обра-

${ }^{1}$ Подразумевание / инотолкование предполагают выбор, между тем выбора между несовместимыми (incompatible) смыслами « $\mathrm{A}_{1} \vee \mathrm{A}_{2} \vee \mathrm{A}_{3} \ldots$ ?» (cf. [18. Р. 182]), т.е. «семантического мерцания», здесь нет. В логике недооценка данного факта приводит к двум типовым трактовкам эквивокации: а) как подмены тезиса при повторе слова со сменой его контекстуальных значений (т.е. как коррелята антанаклазы); б) как двусмысленности. Так, по определению Д. Уолтона эквивокация представляет собой: а) «...смену значения слова при переходе от одной посылки к другой...; б) «...двусмысленность значения слова или выражения при аргументации...». Отсюда следуют: а) вывод: «Двусмысленность сходна с эквивокацией...»; б) использование терминов эквивокация и двусмыссленность как дублетных: «equivocation (or amphiboly)» [19. P. 5, 6, 25].

${ }^{2} \mathrm{Cf}$.: «...zeugma et hipozeuxis, ecce ista duo contraria est...». 
тимости по формуле «ab $+\mathrm{ac} . . \leftrightarrow \leftrightarrow \mathrm{a}(\mathrm{b}+\mathrm{c} . .) »$, где «b» и «c» - однородные члены, «а»- компонент, который в гипозевксисе повторяется, в зевгме же сокращается до одной единицы, становящейся ее общим, связующим звеном [28. Р. 349], ср.:

(6) Пред царем он предстал, и царю он назвал имя и род свой. $\leftrightarrow$ ПРЕД ЦАРЕМ ОН предстал, и назвал имя и род свой.

Употребление зевгмы регулируется правилом, принадлежащим константинопольскому грамматику Флавию Харисию (IV в.): общий ее компонент должен иметь только один смысл ${ }^{1}$ [29. Р. 280 / Art. gram. IV, 4]. Зевгму, подчиняющуюся данному правилу, именуют СЕМАНТИЧЕСКИ ПРОСТОЙ, нарушающую еГО - СЕМАНТИЧЕСКИ СЛОЖНОЙ [28. Р. 349]. ОбщиЙ компоненТ последней объединяет несовместимо разнородные контекстуальные смыслы слова, имеющего омонимы (см. пример 7а), либо полисеманта (7б):

(7) а. МАРК Шагал, верней, ЛЕТЕЛ [Н. Виноградова. Марк Шагал, верней, летел (2006)].

б. Каждый вечер, когда НАД ГОРАМИ и В СЕРДЦЕ туман ... [М. Цветаева. Наши души, не правда ль, еще не привыкли к разлуке... (1910)].

Обратим внимание на два факта:

1) Условием успешной реализации семантически сложной зевгмы является наличие ряда опорных контекстов, роль которых становится очевидной при ее замене гипозевксисом ${ }^{2}$ :

(8) НАД ГОРАМИ И В СЕРДЦЕ туман (а) ↔ туман НАД ГОРАМИ и В СЕРДЦЕ туман (б).

И в случае (8a), и в случае (8б) опорный контекст над горами недвусмысленно поддерживает прямое значение $\mathrm{A}_{1}$ туман 'непрозрачное состояние воздуха вследствие скопления в нем водяных паров', контекст в сердие - переносное $\mathrm{A}_{2}$ туман 'грусть'. Между тем в ситуации двусмысленной речи опорные контексты ex definitione отсутствуют, что отдаляет как зевгму, так и трансформационно связанную с ней антанаклазу от категории двусмысленности. «Мерцания» смыслов « $\mathrm{A}_{1} \vee \mathrm{A}_{2}$ » здесь нет, но есть смена смыслов « $\mathrm{A}_{1,2 . . .}$, соответствующая смене контекстов «b, с ...».

2) Семантически сложная зевгма рассчитана на эффект абсурда, гротеска, но не двусмысленности, т.е. «уравновешивания» ${ }^{3}$ одного смысла дру-

${ }^{1}$ Cf.: «Zeugma est verbum quod in duplici multiplicive sententia aptatur, sed quod omnibus communiter redditur, ut Troiugena, interpres divum, qui numina Phoebi, qui tripodas, Clarii Laurus <, qui sidera sentis> verbum enim sentis singulis quibisque debetur» 'Зевгма объединяет два речения или более одним словом, напр.: Трои сын, глашатай богов, кто Фебову воЛю // ВИДИТ В ДВИЖЕНЬЕ СВЕТИЛ, В ТРЕНОЖНИКАХ, В ЛАВРАХ КЛАРИЙСКИХ [Aen. III: 359-360], слово это, однако, должно иметь один смысл'.

2 Напомним: семантически простая зевгма коррелирует с гипозевксисом, основанным на простом лексическом повторе, сложная - с гипозевксисом, основанным на антанаклазе.

${ }^{3}$ В ситуации двусмысленной речи её адресат должен решить, какое из двух содержаний является её основным смыслом, а какое - «формальным противовесом смысла» [30. C. 276]. 
гим (« $\left.\mathrm{A}_{1} \vee \mathrm{A}_{2} »\right)$; в этом плане такая зевгма ближе к оксюморону и реализации метафоры, чем к фигурам двусмысленной речи.

Указанные два факта не позволяют: а) отнести семантически сложную зевгму к числу фигур двусмысленной речи; б) принять мнение исследователей, относящих зевгму к этому разряду фигур [31. Р. 7-11; 32. Р. 343349; 33. Р. 145; 15. С. 95-100].

4. БУКВАЛИЗАЦИЯ, ИЛИ БУКВАЛИЗАЦИЯ МЕТАФОРЫ ${ }^{1}-$ уПотребление номИнативной единицы, возрождающее ее исходный смысл, вид актуализации внутренней формы. Известно, что «комический эффект возникает, как только мы пытаемся принять буквально выражение, которое <до сих пор> использовалось как фигуральное», в частности в тех случаях, когда абстрактному (moral) выражению возвращается предметный смысл [34. Р. 57]:

(9) АНАЛИз КРОВИ сделан мне. // Он, правда, высосан из пальца, // Но убедителен вполне [В. Берестов. Диагностика (1983)].

Буквализация номинативной единицы (в нашем случае: $\mathrm{A}_{1}$ высосать из пальц̧а 'извлечь') обязательно предполагает наличие опорного контекста (анализ крови); узуальное, более привычное переносное значение $\left(\mathrm{A}_{2}\right.$ 'утверждать что-либо без всяких оснований') снимется контекстом и присутствует лишь на правах коннотации. С этой точки зрения трактовка буквализации как фигуры двусмысленной речи [15. С. 90-92] не выглядит оправданной.

Начиная с Античности элокутивный потенциал категории двусмысленности является традиционным предметом исследовательского внимания ученых, среди которых могут быть указаны Аристотель, Деметрий Фалерский, Квинтилиан, Гермоген Тарсский, Клавдий Гален и др., однако полного и достаточно непротиворечивого описания фигур двусмысленной речи мы не имеем. В трудах названных ученых содержатся лишь отдельные моменты, представляющие интерес с этой точки зрения, тем не менее уже в этот период определился основной состав фигур, выражающих нарочитую двусмысленность: a) антифразис (ирония), в частности хариентизм и его противоположность астеизм (см. раздел 1.1); б) аллегория, в частности энигма (см. раздел 1.3.1); в) некоторые тактики, связанные с омонимией и сдвигом, а также амфиболией в узком значении термина (см. раздел 2). Немногочисленные монографические исследования, принадлежащие, в частности, поэту и литературному критику У. Эмпсону [10], философу Д. Уолтону [19], литературоведу-медиевисту А. Осса-Ричардсону [11], удалены от методов лингвистического анализа и лингвистической понятийно-терминологической системы, которая в этих работах представлена фрагментарно.

Так, в монографии А. Осса-Ричардсона, написанной под влиянием идей У. Эмпсона, отмечены: 1) ирония (без необходимой детализации); 2) метафора (без указания контекстуального типа); 3) аллегория (безотносительно к метафоре и без релевантного для анализа античной и средневе-

\footnotetext{
${ }^{1}$ Имеется в виду метафора in genere, т.е. метафора в широком, античном смысле, ср. греч. $\mu \varepsilon \tau \alpha \varphi \varepsilon ́ \rho \varepsilon \imath v$ 'переносить' (см. раздел 1.3.1).
} 
ковой научной литературы противопоставления аллегории in genere и аллегории еx simili); 4) энигма (безотносительно к аллегории); 5) дилогия (в античном значении 'двусмысленность'); 6) каламбур («рun»); 7) эквивокация, трактуемая как «mendacious ambiguity» 'лживая двусмысленность', «witty ambiguity» 'остроумная двусмысленность' [11]; попытки систематизации отсутствуют.

В диссертации М.А. Южанниковой в разделе «Разновидности приемов двусмысленности и критерии их выделения» [15. С. 77-102] значатся: 1) антифразис и астеизм; 2) амфиболия; 3) антанаклаза; 4) буквализация метафоры; 5) дилогия; 6) зевгма; 7) каламбур. Однако: а) как показано нами выше, антанаклазу, зевгму и буквализацию метафоры относить к числу фигур двусмысленной речи нецелесообразно; б) каламбур представлен рядом приемов, ср.: «...каламбур является родовым понятием по отношению к дилогии, антанаклазе, амфиболии, буквализации метафоры, а также к некоторым другим (использование паронимии, различных сдвигов и т.д.)» [15. С. 101], причем многие из этих приемов с двусмысленностью не связаны. Не только каламбур, но и двусмысленность (amphiboly) в широком, исходном смысле термина нередко трактуется как прием, «deceptive device» 'уловка', без указания и анализа конкретных разновидностей [35. P. 21-25]. Причастность ряда средств (таксономических переносов, метонимии, незамкнутой метафоры, фонетической аллюзии, параграммы и т.д.) к анализируемой сфере практически не отмечена ${ }^{1}$, дефиниции некоторых (аллегории, энигмы, дилогии и др.) требуют уточнения; общая логически непротиворечивая классификация приемов двусмысленной речи отсутствует.

Рассмотрим и систематизируем приемы, соответствующие представленным выше критериям двусмысленности.

\section{1. Семантическая производность как основа двусмысленности.}

Нарочитая двусмысленность, намек могут быть созданы за счет контекстуально дефектного применения практически любых переносов: таксономических, метонимического или метафорического ${ }^{2}$. Рассмотрим эти средства в указанной последовательности.

1.1. Таксономические переносы. В 1867 г. шотландский языковед А. Бэн (1818-1903) предложил ассоциативно-психологическую классификацию фигур, в частности переносов, на основе «трех фундаментальных

\footnotetext{
${ }^{1}$ Недостаточное внимание специалистов к незамкнутой метафоре (одной из наиболее заметных примет символизма) и аллегории, в частности энигме, приводит к ограничению нарочитой двусмысленности сферой языковой игры: «Если говорящий прибегает к двусмысленности сознательно, это является провокацией, языковой игрой или флиртом» [36. Р. 263] (ср., в частности: [37. С. 81]).

${ }^{2}$ О подходах к систематизации переносов см.: [38]. Переносы трактуются здесь как приемы образования номинативных единиц (с. 11). Как известно, термин прием соот-

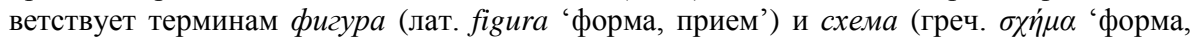
прием'), ср. у Квинтилиана: «...ad figuras, quae $\sigma \chi \dot{\eta} \mu \alpha \tau \alpha$ Graece vocantur...» 'к фигурам, кои схемами греки именуют' [17: 86 / Inst. orat. IX, 1: 2].
} 
законов мышления»: сходства (similarity), смежности (contiguity) и контраста (contrast), причем с последним типом соотнес «фигуры контраста», прежде всего антитезу [39. Р. 20-21]. К таксономическим переносам (таким, как перенос с рода на вид, с вида на вид, с вида на род) представляется целесообразным применить два типа ассоциаций: по сходству и по контрасту. Логично полагать, что сходство объединяет вид с родом, виды же внутри рода противопоставлены присущими им специфическими различиями (differentiae specificae) по контрасту ${ }^{1}$. Таксономические переносы могут использоваться для создания подтекста. Так, следующие образцы переносов с вида на род (см. пример 10а) и с рода на вид (см. 10б) содержат обидные, а зачастую и не всегда политкорректные намеки:

(10) а. И не повернув / головы кочан // и чувств / никаких / не изведав, // берут, / не моргнув, / паспорта ДАТЧАН // И РАЗНЫХ / ПРОЧИХ / шведов ${ }^{2}$ [В. Маяковский. Стихи о советском паспорте (1929)].

б. У оппонента вместо головы совсем другая часть тела [41. С. 140].

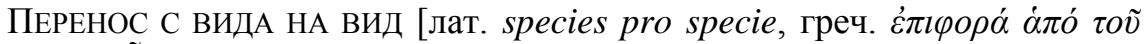

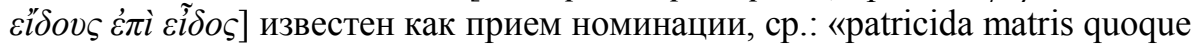
aut fratris» 'отцеубийство матери или брата' [17. P. 80 / Inst. orat. VIII, 6: 35], «ut patricidam dicimus qui occiderit fratrem $\langle\ldots\rangle$ suum vocabulum non haberent» 'так, мы называем отцееубйцей и того, кто убил своего брата, ибо слова братоубийца <в латыни> не существует' [42. P. 400 / De art. gram. III, 6: 1-2]; «И с <мужского > рода на <женский> род: Я похоронил моего МЕРТВОГО ${ }^{3}$ (Бытие, 23: 8), где мужской род употреблен вместо женского» [43. Р. 441-442]. Этот тип переноса способен служить и как более или менее прозрачный, в зависимости от наличия / отсутствия опорного контекста, намек на некий иной вид внутри того же рода, ср. шутл. инженер по укладке ГРУЗОВ, пригласить на РЮмКУ чая и:

(11) Долго еще, во время даже самых прибыточных сделок, купџы, отправляясь в трактир запивать их чаем, поговаривали об антихристе [Н.В. Гоголь. Мертвые души (1842)].

Использование данного переноса связано также с известным приемом эзопова языка - перенесением действия в иные страны и времена:

(12) Пока безумный наш султан // дорогу нам сулит к острогу, // возьмемся за руки, друзья, // возьмемся за руки, ей-богу [Б. Окуджава. Союз друзей (Старинная студенческая песня) (1967)].

Как перенос с вида на противоположный вид целесообразно рассматри-

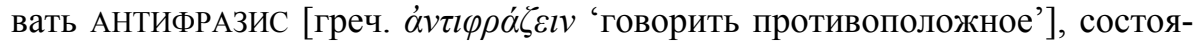

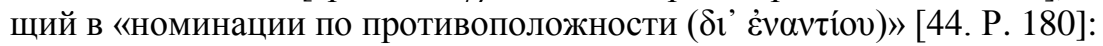

\footnotetext{
${ }^{1} \mathrm{C}$ этой точки зрения трудно принять мнение А. Бланка о том, что переносы данного типа основаны только на «сходстве понятий» [40. Р. 42, 46].

2 Судя по контексту, имеются в виду представители малых государств, не достойные, по мнению «учтивого чиновника», уважения (ср. в предтексте: «К другим - / отношение плевое».

${ }^{3}$ Cf.: «Sepeliui mortuum meum»; речь идет о Cappe.
} 
(13) Люблю я критиков моих. // На шее одного из них, // благоуханна и гола, // сияет антиголова!.. [А. Вознесенский. Антимиры (1961)].

К числу тактик, реализующих технику антифразиса, отнесем следующие:

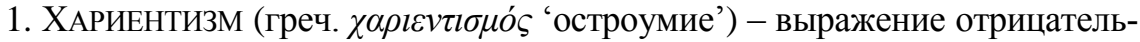
ной оценки под видом положительной, «колкость под личиною приятности (festiva dictio, cum amoenitate mordax)» [45. P. 39 / De fig. sent., 3]:

(14) На Павелецккой-радиальной // Средь ионических колонн // Стоял мужчина идеальный // И ПИЛ ТРОЙНОЙ ОДЕКОЛОН [И. Иртеньев. На Павелецкой-радиальной... (1991)].

Хариентизм лежит в основе тактики ЭЛЕВАЦИИ (лат. elevatio 'поднятие'), выражающей иронию под видом энкомия (cf., е.g.: [46. Р. 195-196 / De fig. sent., 15]) ${ }^{1}$ :

(15) А я, неведомый Пиита, // В восторге новом воспою // Во след Пиита знаменита // Правдиву похвалу свою [А.С. Пушкин. Ода его сиятельству графу Д.И. Хвостову (1825)].

Хариентизм может сопровождаться и усиливаться АПОФАЗИЕЙ (греч. $\dot{\alpha} \pi o ́$ 'вопреки' + $\dot{\alpha} \sigma \iota \varsigma$ 'сказанное'), состоящей в косвенном, как бы нечаянном опровержении собственной только что высказанной точки зрения (что влечет нарушение логического закона непротиворечия), например с целью иронии:

(16) Сотрудник по математике нашел, что знания у Маши есть. Но их немного, и все они НЕПРАВИЛЬНЫЕ [Э. Успенский. 25 профессий Маши Филипенко (1988)].

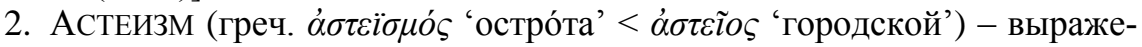
ние положительной оценки под видом отрицательной:

(17) Ой, Вань, какие акробатики! // Смотри, как вертится, нахал! [В. Высоцкий. Диалог у телевизора (1973)].

Первоначально термин астеизм применялся в более широком смысле и трактовался как фигура изящной, «городской речи», которая противопоставлялась грубой «деревенской». В трактате Сервия Доната (IV в.) читаем: «[A]stismos est tropus multiplex numerosaeque virtutis. namque a putatur quidquid simplicitate rustica caret et faceta satis urbanitate litum est...» 'Астеизм - троп многих и разнообразных достоинств, ибо все, что освобождено от деревенской простоты и в достаточной степени обработано городским умом, считается астеизмом’ [42. P. 402 / De art. gram. III, 6: 16-18].

3. ЭПитРОП (греч. غ̇лıтроли́ 'намек') - притворное поощрение действия:

(18) а. Ешь ананасы, / рябчиков ж⿻й, // День твой последний / приходит, буржуй [В. Маяковский. Владимир Ильич Ленин (1924)].

б. Веселись, юноша, в юности твоей, и ходи по путям сердца твоего и по видению очей твоих; только знай, что за все это Бог приведет тебя на суд [Экклезиаст, 11: 9].

\footnotetext{
${ }^{1}$ В качестве примера Аквила Романус указывает на те места речи Цицерона в защиту Луция Мурены, которые содержат внешне хвалебные характеристики, данные Цицероном Сульпицию Руфу.
} 
Цель данной тактики - «...отвратить нас от бесчинства, внушить нам ужас и раскаяние путем мнимого позволения перейти границу дозволенного» [47. Р. 148]. На эпитропе основан жанр «вредных советов» Г. Остера.

К числу таксономических переносов следует отнести ГЕТЕРОЗИС (греч. $\dot{\tau} \varepsilon \rho o i \omega \sigma \iota \varsigma$ 'изменение'), состоящий в использовании одной грамматической категории, например времени, рода, числа, лица, в значении другой. Грамматические значения формируют таксономические микроиерархии, например: 'числО' (родовое понятие) 'ед. ч.', 'двойственное число', 'мн. ч.' (видовые понятия); 'лицо' (родовое понятие) '1-е лицо', '2-е лицо', '3-е лицо' (видовые понятия); 'РОД' (родовое понятие) 'жен. род’ и 'муж. род’ (видовые понятия) и др.; ещё Л. Валла (1407-1457) отметил, что «значение времени относится к значению прошедшего времени так же, как род к виду» [48. Р. 270]. С этой точки зрения гетерозис (эналлагу, грамматическую метафору) логично рассматривать как перенос с вида на вид. По наблюдениям Н.Ю. Осокиной и С.Б. Дектерева [49], грамматическая метафора способна выражать намек: Не ОЧЕНЬ-то он женат! (здесь наблюдаем осмысление относительного прилагательного как качественного, а значит, поддающегося градуальной оценке).

1.2. Метонимия. Понятие смежности ввел А. Бэн, описавший на этом основании «фигуры смежности (figures of contiguity)», к которым он отнес виды метонимии, включая синекдоху и смещение эпитета [39. Р. 41-45]. Термин $\mu \varepsilon \tau \omega v v \mu i \alpha$ не используют ни Аристотель, ни Деметрий Фалерский; данный термин впервые встречается в перечне Трифона (І в. до н. э.), здесь же находим первое описание метонимической формулы:

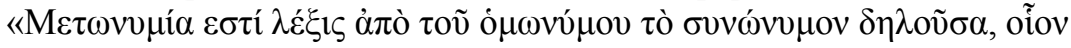

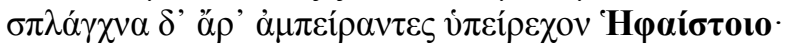

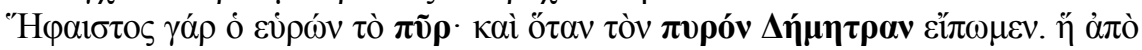

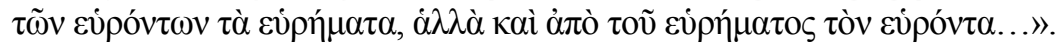

'Метонимия есть выражение, равнозначность чрез равноименность поясняющее, например: Но утробы, пронзив, над пылавшим Гефестом вращали. Ибо Гефест добыл огонь; подобным же образом и пшеницу Деметрою называют: изобретенное по изобретшему, а всех изобретших по изоб-

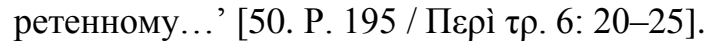

Как виды метонимических формул должны рассматриваться:

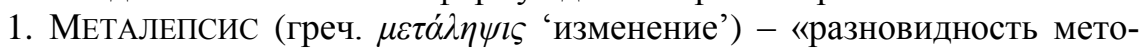
нимии, состоящая в замене логически предшествующего понятия логически последующим или наоборот» [23. С. 230]. Заметим: а) отношения следования и предшествования связывают скорее действия и ситуации, чем понятия; б) если референтную микросистему следования и предшествования дополнить логически предполагаемым звеном отношений сопутствования, то в таком случае под металепсисом следует понимать обозначение одной ситуации через другую, так или иначе с нею связанную. Эта особенность металепсиса удобна для реализации эвфемии: 
(19) Я в весеннем лесу пил березовый сок, // С ненаглядной певуньей в стогу ночевал [Е. Агранович. Я в весеннем лесу... (1956)].

2. Следующие два вида синЕКдоХи:

a) PARS PRO TOTO, ср. показывать пальием и:

(20) У него <борода> растет, а у меня не растет, - частенько говаривал Пушкин, показывая ногтями на Захарьина [Д. Хармс. Анекдоты из жизни Пушкина (1939)].

б) TOTUM PRO PARTE:

(21) Барыня в летах, но нарядная и авантажная <..> с большим бюстом, подтянутым корсетом к самому носу, сидела на диване [Н. Кузьмин. Круг царя Соломона (1964)].

Метонимические ассоциации, в противоположность метафорическим, традиционно оцениваются как более реалистичные и предсказуемые, отсюда, видимо, невысокая активность метонимии как фигуры двусмысленной речи.

1.3. Незамкнутая метафора. Под незамкнутой принято понимать метафору с отсутствующим ключевым словом:

(22) Каждый вечер по легким и зыбким мостам // Мы выходим друг другу навстречу. // Чуть завижу знакомый вдали силуэт, - // Бьется сердце то чаще, то реже... [М. Цветаева. Не гони мою память! Лазурны края... (1910)].

В таких контекстах метафора «...утрачивает однозначность», превращаясь в «неясный, туманный образ-символ» [51. С. 120], ср. возможные конъектуры: по мостам реальным $\left(\mathrm{A}_{1}\right)$ ? воображаемымм $\left(\mathrm{A}_{2}\right)$ ? мостам грез, мечтаний $\left(\mathrm{A}_{3}\right)$ ? памяти $\left(\mathrm{A}_{4}\right)$ ? снов $\left(\mathrm{A}_{5}\right)$ ? Считается, что в случае двусмысленности значения отчетливы (distinct), в случае неясности - объединены в нечленимый комплекс в рамках более широкого значения; так, в выражении $У$ него есть ТЕТКА неясно, тетка по отцу или тетка по матери имеется в виду [52. Р. 167]. Заменим неясное и неоднозначное наименование мосты ясным и однозначным связь через $\mathrm{crbl}$ :

(23) Нас неразрывной и вечной загадкой // Сон сочетал [М. Цветаева. Связь через сны (1910)].

Оценка данной субституции такова: «Nommer un objet, c'est supprimer les trois quarts de la jouissance du poème, qui est faite de deviner peu à peu: le suggérer, voilà le rêve. C'est le parfait usage de se mystère qui constitue le symbole...» 'Назвать предмет означает уничтожить три четверти наслаждения стихами, которые написаны именно для разгадывания - слово за словом; создать такое - вот мечта. Совершенство в применении этой тайны составляет суть символа' [53. Р. 60]. В силу своей семантической емкости и многоплановости незамкнутая метафора стала приметой символизма как литературного направления.

1.3.1. Аллегория. Анализ различных трактовок аллегории неоднократно заставлял ученых констатировать «неопределенность значения» термина аллегория [54. Р. 8], «путаницу в определениях аллегории» [55. Р. 17], а зачастую приводил к пессимистическим выводам: «Если мы начнем с про- 
стого, казалось бы, вопроса “Что есть аллегория?”, то мы едва ли достигнем чего-либо», поскольку «аллегория ускользает от определений» [56. Р. 46, 49; cf., е.g.: 57. Р. 161; 58. Р. 5; 59. Р. 2, еtc.]. Адекватное осмысление феномена аллегории затруднено следующими обстоятельствами: а) удаленностью категориального аппарата теоретических исследований аллегории от общей, в частности контекстуальной классификации метафор; б) существенным изменением объема понятия аллегории по мере его исторического развития.

Аллегория как предмет определения. Аллегория традиционно определяется как развернутая метафора: «Метафора продленная и развернутая есть аллегория» [59. Р. 6; cf. 11. Р. 455, 464], отсюда вывод: «...каждая метафора является отчасти и аллегорией» [60. Р. 60], т.е. «соотношение аллегории и метафоры квантитативно», а «аллегория есть метафора, продленная на длину всей фразы (и более)» [28. Р. 399]. С этой точки зрения термины аллегория и развернутая метафора рассматриваются как синонимы [20. Р. 21]. Традиция такого понимания аллегории восходит к Античности: «Iam quum fluxerunt plures continuae translationes, alia plane fit oratio. Itaque hanc Graeci appellant $\dot{\alpha} \lambda \lambda \eta \gamma$ ó́ $\alpha v$, nomine recte, genere melius ille, qui ista omnia translationes vocat» 'Когда же следует подряд много метафор, это делает речь иносказательной. Поэтому греки и именуют такой прием аллегорией; название верное, но лучше поступает тот, кто все это называет метафорами' [61. Р. 236 / Orat. XXVII:

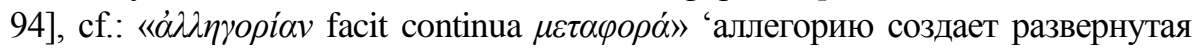
метафора' [17. Р. 101 / Inst. orat. IX, 2: 46]. Начиная с этой эпохи «...доминирующие трактовки аллегории никогда не отклонялись далеко от риторической дефиниции, кодифицированной Квинтилианом: “развернутая метафора". Последняя до сих пор остается общим местом учебников и словарей литературоведческих терминов» [62. Р. 56]. Анализ, однако, показывает, что данная типовая дефиниция нуждается в корректировке с учетом места аллегории в контекстуальной классификации метафор. Роль опорного микроконтекста, который делает возможной более или менее точную расшифровку метафорического переноса, играет ключевое слово, или слово-«отгадка». Такое слово синтаксически связано со словом-носителем переноса, основная его функция - прямое или косвенное указание на основной субъект данной метафоры, т.е. ее интерпретация [63]:

(24) Среди сорняковых зарослей многобожия Он находил малье нивы и сеял на них доброе семя ВЕРЫ [Н. Сербский. Вера образованных людей (1928), пер. С. Луганской].

Метафора семя интерпретируется с опорой на контекст (веры) как 'начало, источник'. Метафору, имеющую при себе ключевое, «отгадочное» слово, принято именовать, вслед за Ю.И. Левиным, ЗАМКнУтой. Поиск основного субъекта незамкнутой метафоры затрудняется отсутствием опорного контекста. Многоплановый характер содержания такой метафоры задает сферу ее действия, делая возможным ее использование:

1) в игровых целях, например в жанре загадки: 
(25) Кто утром ходит на четырех ногах, днем на двух, а вечером на mpex? $^{1}$

2) в целях эвфемии:

(26) [Врач - больному (взяв шприц)]: - Приготовь-ка для работьл плацдарм! [Кинофильм «По улицам комод водили» (1978)].

3) в целях косвенного поучения, например в жанре пословицы:

(27) В чужом глазу сучок видим, а в своем бревна не замечаем.

Контекстуальные типы метафор были описаны еще Аристотелем, ср.:

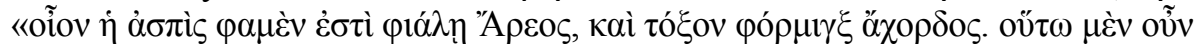

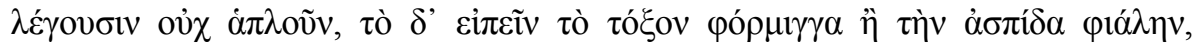
$\dot{\alpha} \lambda \lambda о \tilde{v} »$ 'Называя щит фиалом Ареса, а лук - бесструнной лирой, мы употребляем метафору непростую, называя же лук лирой или щит фиалом (курсив наш. - B.M.), мы используем метафору простую' [64. P. 128-129 / Rhet. 1412b.35-1413a.1]. А.А. Потебня именует незамкнутую метафору «полной, т.е. такой, в словесном выражении которой нет явственных указаний на ее значение» [65. С. 238]. Замкнутая («непростая») и незамкнутая («простая», «полная») метафоры выявлены по наличию / отсутствию ключевого слова, т.е. по контекстуальному параметру, что дает основание назвать представленную выше классификацию метафор кОНТЕКСТУАЛЬНОЙ.

Значимым параметром рассмотрения развернутой метафоры, а следовательно и аллегории как ее вида, представляется логическая последовательность компонентов. С этой точки зрения в метафорической цепочке могут быть выделены две части: а) исходная метафора; б) метафорическая разверт$\kappa a$. Создание аллегории происходит в результате развертывания незамкнутой исходной метафоры. Такой исходной метафорой может стать слово семя:

(28) ${ }^{5}$...вышел сеятель сеять семя свое, и когда он сеял, иное упало при дороге и было потоптано, и птицы небесные поклевали его; ${ }^{6}$ а иное упало на камень и, взойдя, засохло, потому что не имело влаги; ${ }^{7}$ а иное упало между тернием, и выросло терние и заглушило его ; а иное упало на добрую землю и, взойдя, принесло плод сторичный [Еванг. от Луки 8].

Развернутая незамкнутая метафора, лежащая в основе данной притчи, представлена лексикой тематического ряда «Посев» (семя, сеятель, сеять, взойти, еtс.). Истолкование («мораль») здесь отсутствует; «темная аллего-

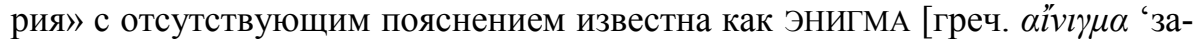
гадка'], «сокровенный смысл выражающая» [66. Р. 330].

Определим АЛЛЕГОРИЮ как развернутую незамкнутую метафору, служащую дидактическому разъяснению. Замкнутая метафора благодаря наличию опорного контекста поддается однозначной интерпретации, а потому к числу фигур двусмысленной речи не принадлежит; с учетом данного факта трудно принять концепции (е.g.: [10. Р. 1-2, 25-26; 67. Р. 1, 10, 30; 68. Р. 28; 11. Р. 41, 384], еtc.), авторы которых относят метафору, без уточнения ее контекстуального типа, к сфере двусмысленности.

\footnotetext{
${ }^{1}$ Ср. замкнутые метафоры: утро жизни, вечер $\underline{\text { жизни. }}$
} 
В специальной литературе понятие аллегории регулярно применяется к развернутым замкнутылм метафорам. Так, повесть Дж. Баньяна «Путешествие Пилигрима» традиционно именуют «религиозной аллегорией» (e.g.: [69. Р. IX-X; 70. Р. 19], etc.), однако поскольку данная повесть содержит значительное число замкнутых метафор, ее следует рассматривать как лишенную аллегоризма в строгом смысле данного термина:

(29) a. As they talk they come to the Slough OF DESPOND. 'Так, ведя беседу, они дошли до Болота Уныния'.

б. If you do not want to return to your old home - you can send for your wife and children to live in the village OF MORALITY. 'Если вы не хотите возвращаться в свой старый дом, вы можете послать за своей женой и детьми и поселиться в селении МОРАЛИ’ [Ј. Bunyan. The pilgrim's progress (1678)].

Традиция такого понимания аллегории восходит к Античности, ср.: «Habet usum talis allegoriae frequenter oratio sed raro totius; plerumque apertis permixta est» 'Аллегории редко охватывают всю речь: многие смешаны с открытой <речью>' [17. P. 82 / Inst. orat. VIII, 6: 47]. Аллегорию без пояснения «открытой речью» именуют полной (allegoria tota), поясненную - неполной, смешанной (allegoria commixta). Г. Лаусберг [28. Р. 400], поясняя различие между этими двумя типами, как пример неполной аллегории приводит следующую фразу из речи Цицерона «De domo sua» 'О своем доме' (I в. до н. э.):

(30) [C] Um SENATUM a gubernaculis deiecisses, populum e navi exturbasses, ipse archipirata cum grege praedonum impurissimo plenissimis velis navigares 'Если штурвал СЕНАТА бросите, народ римский с корабля низвергнется, и полными парусами править будет пиратский капитан со своими грязными приспешниками'.

Данная развернутая метафора является: а) скорее изобразительной, чем дидактической; б) замкнутой (штурвал СЕНАТА), т.е. утрачивает необходимость в интерпретации, а значит, и основные, системообразующие параметры аллегории sensu stricto.

Аллегория in genеre и аллегория ех simili. Историческое развитие понятия. По мере своего исторического развития понятие аллегории претерпело сужение. Исходное понимание аллегории удалено от современного: «Наши современные представления об аллегории как элемента аналитического словаря бесполезны в этом контексте (Античности. - B.M.). Древнее значение шире и сложнее для определения» [71. Р. 20]. Наиболее широкое понимание аллегории отражено в следующем типовом определении: «[Т]ермин аллегория относится к способу рассказа или показа одной вещи и подразумевания иной» [72. Р. 1; cf.: 73. Р. 83; 74. Р. 2; 59. Р. 6]. Подобные дефиниции находим и в средневековых трактатах: 1) Беды Достопочтенного (673-735): «Allegoria est tropus, quo aliud significatur quam dicitur» 'Аллегория есть троп, которым обозначается не то, о чем говорится’ [75. P. 615 / De schem., 12]; 2) Исидора Севильского (560-636): «Allegoria est alieniloquium. Aliud enim sonat, aliud intelligitur» 'Аллегория есть иносказание. Одно выражает, другое же подразумевает’ [76. Р. 59 / Etym. I, 36: 22]. В рамках данной дефиниционной традиции аллегория по- 


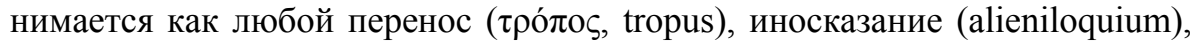
изменение смысла (permutatio): «Allegoria est tropus, quo aliud significatur quam dicitur, ut et iam tempus equum fumantia solvere colla, hoc est 'carmen finire'. huius species multae sunt, ex quibus eminent septem, ironia antiphrasis aenigma charientismos paroemia sarcasmos astismos» 'Аллегория есть троп, который одно говорит, а иное обозначает, например: Время настало коней запотевшие шеи распрячь, т.е. “песню окончить”. Виды аллегории различны, из них главнейших семь: ирония, антифразис, энигма, хариентизм, паремия, сарказм, астеизм' [42. P. 401 / De art. gram. III, 6: 26-30] ${ }^{1}$.

Дефиницию данного типа находим и в «Риторике к Гереннию», ср.: «Permutatio est oratio, aliud verbis, aliud sententia demonstrans» 'Аллегория есть речь, которая словами одно, смыслом же другое выражает’. Анонимный автор рассматривает три вида аллегории: развернутую метафору, метафорическое использование имени собственного в значении нарицательного (т.е. pronominatio, фоссианову антономасию) и антифразис [77. P. 342-343 / IV, 34: 255]. Анализируя аллегорию, Квинтилиан называет два ее вида - антифразис и развернутую метафору: «At $\dot{\alpha} \lambda \lambda \eta \gamma o \rho i \alpha$, quam inversionem interpretantur, aut aliud verbis aliud sensu ostendit aut etiam contrarium. Prius fit genus plerumque continuatis tanslationibus...» 'A $A \lambda \eta \gamma \gamma o \rho i \alpha$ же, которая <нна латынь> как inversio переводится, либо указывает на одно в словах, а на другое в значении, либо на нечто противоположное. Первый тип обычно производится путем развертывания метафор' [17. P. 81 / Inst. orat. VIII, 6: 44]. Деметрий Фалерский как пример аллегории приводит

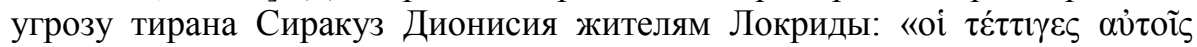

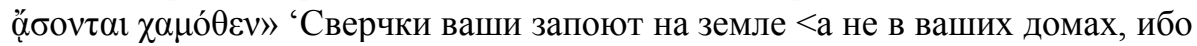

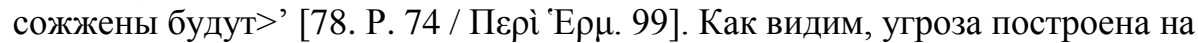
металепсисе. В трактате Я. Коменского (1592-1670) читаем: «Tropus ad Periodi usque finem continuatus, ALLEGORIA dicitur» 'Аллегорией называется троп, развернутый на целый период’. Среди наиболее распространенных («celebratissimæ») видов аллегории ученый называет метафору, иронию и гиперболу, отмечая также, вслед за Г. Фоссом, метонимию и синекдоху. Вместе с тем, по его мнению, «allegoriæ metaphoricæ creberissimæ

${ }^{1}$ Ещё Квинтилиан высказал сомнение в том, что такие средства, как сарказм, астеизм, антифразис и паремия являются видами аллегории: «Sunt etiam, qui haec non species allegoriaesed ipsa tropos dicant; acri quidem ratione, quod illa obscurior sit, in his omnibus aperte appareat, quid velimus. Cui accedit hoc quoque, quod genus, cum dividitur in species, nihil habet proprium, ut arbor pinus et olea et cupressus, et ipsius per se nulla proprietas; allegoria vero habet aliquid proprium» 'Есть, однако, и те, кто говорит, что эти средства суть не виды аллегории, а тропы, подкрепляя своё мнение тем весомым аргументом, что аллегория чрезвычайно темна, в то время как все эти средства ясно выражают то, что мы имеем в виду. К этому можно добавить то соображение, что данные средства не являются видами аллегории таким же образом, как видами дерева являются сосна, олива и кипарис, ибо род не обладает особенностями, которые присущи видам, аллегория же такой особенностью обладает (например, свойством неясности. - B.M.)' [17. Р. 83 / Inst. orat. VIII, 6: 58]. 
sunt, et suavissimæ» 'метафорические аллегории наиболее частотны и наиболее приятны’ [79. Р. 501 / Jan. V, 56-59].

Античными и средневековыми авторами в понятии аллегории объединя-

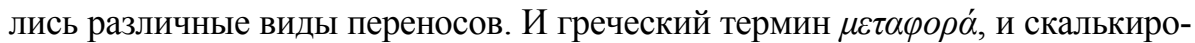
ванный с него латинский translatio первоначально обозначали любой перенос, т.е. употреблялись в широком смысле 'метафора in genere'. Так, начиная с периода ранней Античности широко используется следующее определе-

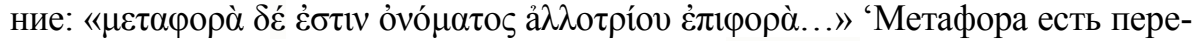
несение имени на нечто иное’ [80. P. 31 / Poet. 1457b.10]. Приведенные выше трактовки аллегории отчасти сближают ее с метафорой in genere.

$\mathrm{C}$ течением времени и понятие метафоры, и коррелирующее с ним понятие аллегории стали трактоваться более узко, т.е. как перенос по сход-

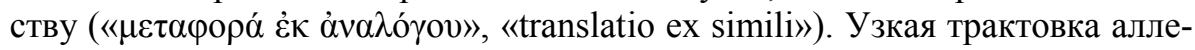
гории как развернутой метафоры еx simili, по сравнению с понятием аллегории in genere, - «поздняя традиция» [81. Р. 15-16].

2. Тождество формы как основа двусмысленности. В этом случае интерпретации выбор также происходит между единицей $\mathrm{A}_{1}$ и единицей $\mathrm{A}_{2}$, но при этом $\mathrm{A}_{1}$ и $\mathrm{A}_{2}$ связаны не отношениями семантической производности (см. раздел 1), а тождеством формы. Данному условию отвечают:

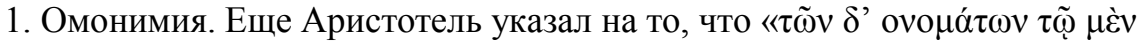

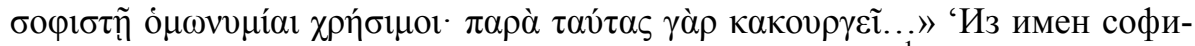
сту омонимы полезны, ибо чрез них злохитрости творит, ${ }^{1}$ [82. P. 110 / Rhet. 1404b.35]. Омонимия традиционно используется и как основа игровой двусмыслицы, ср.:

(31) Три теленка - сколько ног? [Загадка].

Давно замечено, что основой такой двусмысленности становится нарочитый сдвиг. Гермоген Тарсский приводит следующий пример амфиболии

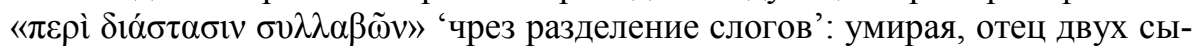
новей, одного из которых звали Леон, другого - Панталеон, оставил уст-

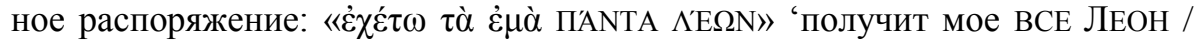
ПоЛУчИт мое ПАНТАЛЕОН' [83. Р. 141].

На сдвиге в письменной речи строится каламбур, известный как ГЕТЕ-

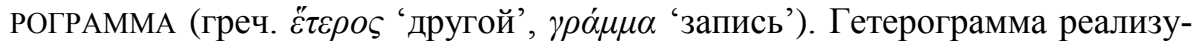
ется в двух формах записи:

a) слитной:

(32) Тьведьмадоннароза [С. Федин (1999)].

б) с перестановкой пробелов:

(33) а. Я тем, что жив и пью вино, // свою победу торжествую: // я мыслли, следователь, но - // я существую [И. Губерман. Первый иерусалимский дневник (2004)].

б. В первом же мотеле, который я посетил - «Пондерозовая Сосна», я нашел, среди дюжины явно человеческих адресов, следуюшую мерзость:

\footnotetext{
${ }^{1}$ Cf. latine: «Nomina autem ambigua Sophistae conveniunt; ex iis fallaciter concludit...» 'Имена двусмысленные софисту удобны, ибо из них ложное выводит' [82. Р. 387].
} 
Адам Н. Епилинтер, Есноп, Иллиной. Мой острый глаз немедленно разбил это на две хамских фразы, утвердительную и вопросительную [В. Набоков. Лолита (1955)] ${ }^{1}$.

В устной речи эксплуатируется так называемое ИЗМЕНЕНИЕ АКЦЕНТА, варьирующее смысл высказывания, ср. Тыве́дьмадо̀ннаро́за и Тывведь-

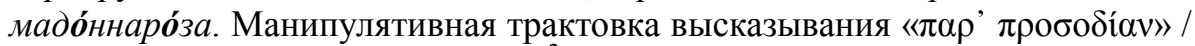
«in accentu» [8. P. 582 / De soph. I] ${ }^{2}$ известна как АКцЕНТНАЯ УЛОВКА (англ. accent fallacy).

2. Два вида полисемии. В этих случаях:

2.1. ЛСВ полисеманта восходят к одной производящей единице, но между собой отношениями производности не связаны, ср. заключение 1 и заключение 2 в примере (35), дичь $1<$ дикая птица, дичь $2<$ дикий вздор (здесь универбация выступает как источник кодериватов):

(34) Здесь в указатель глядеть не приходится, // Можно здесь разом постичь, // Что на картинах пред нами находится // Дичь, господа, только дичь [Д. Минаев. К картине «Битая дичь» г. Гравертл (1863)].

Как известно, деривация подобного рода является и источником омонимии - случая, когда имеет место «...независим[ое] (иногда - в разное время) образование от одной и той же основы при помощи одних и тех же аффиксов, но каждое в специализированном значении...»: ветрянка 'мельница' и ветрянка 'оспа', приемник 'учреждение' и приемник 'устройство для приема чего-либо’ [84. С. 345], ср. также выдержка ${ }_{1}$ и выдержка ссылка $a_{1}$ и ссылка $a_{2}$ в примере (35). В функциональном отношении случаи такой омонимии и полисемии (2.1) равноценны. Пример их совместного использования:

(35) С товарищем Сталиным трудно спорить. Ты ему цитату, он тебе заключение. Ты - выдержку, он - ссылку [К. Радек [?]. Из выступления на съезде // 85. С. 249].

2.2. Семантически производные ЛСВ утрачивают связь с производящимп ЛСВ, иными словами, «...теряют значительную часть своей исходной семантики (“выветриваются”), фразеологизируются и грамматикализируются, т.е. постепенно превращаются в формальные, почти асемантические единицы...», в «преддверие омонимии» [86. С. 15]

(36) а. Дорогой мой первоклассник [Газетный заголовок].

б. Подари своей девушке Бикини! [Реклама туристического агентства].

${ }^{1}$ При построении гетерограммы «...исходные слова заменяются их омофонами» [20. С. 24], ср.: Адам не пил. Интересно, пил ли Ной?

${ }^{2}$ Клавдий Гален (II в. н. э.) развивает концепцию Аристотеля, который, рассматри-

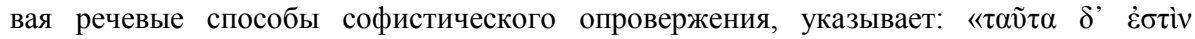

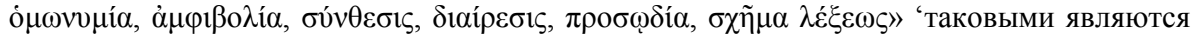
омонимия, амфиболия, соединение, разъединение, акцент, форма речи' [82. p. 278 / Soph. elench. IV, 165b: 24-27].

3 Постепенный «разрыв первоначально единой семантики многозначного слова» считается «...наиболее продуктивным и исторически наиболее сложным фактором появления омонимии» [84. С. 345]. 
Рассмотренные случаи (1) и (2) нарочитой двусмысленности, возникающей на основе тождества формы, целесообразно обозначать термином дилогия ${ }^{1}$. В настоящее время данный термин применяется в двух смыслах: а) в широком 'двусмысленность' (см. Введение); б) в более узком 'фигура речи', ср.: «ДилоГИя <...>. Фигура речи, состоящая в одновременном употреблении слова в двух разных смыслах в пределах одного и того же высказывания»: «И ЖЕЛЕЗНАЯ лопата В каменную грудь, Добывая мель и злато, врежет страшный путь - здесь железный одновременно как а) сделанный из железа и б) непреклонный <...», «Вообще, в Сибири, несмотря на холод, служить очень ТЕПЛО» [23. С. 134]. Здесь, однако: 1) приведены примеры вполне однозначно понимаемых: а) олицетворенной метонимии (железная лопата ('землекоп’), действующая с непреклонностью человека); б) катахрезы - конфликта внутренней формы метафоры тепло (служить) и прямой номинации холод (в Сибири), т.е. под понятие «смысл слова» подводится еще и внутренняя форма; 2) определение не дает возможности отграничить дилогию от ряда других приемов двусмысленной речи: контекстуально дефектных таксономических переносов, метонимии и незамкнутой метафоры, поскольку каждый из них «состоит в одновременном употреблении слова в двух разных смыслах в пределах одного и того же высказывания». Возникает вопрос о языковой основе дилогии и таксономической ценности соответствующего термина. Думается, что за этим термином следует оставить тот не имевший до недавнего времени собственного обозначения тип двусмысленности, который создается на основе тождества формы.

Заметим: в случае (2.2) при СОХРАНЕНИИ между ЛСВ полисеманта ОЩУТИМЫХ ОТНОШЕНИЙ СЕМАНТИЧЕСКОЙ ПРОИЗВОДНОСТИ слеДУет ГОВорить не о полисемии как основе двусмысленности, а о таксономических переносах, метонимии и незамкнутой метафоре (см. раздел 1); чем слабее отношения семантической производности, связывающие ЛСВ полисеманта, тем больше оснований констатировать, что базой для сближения слов выступает тождество формы. Без внесенного нами уточнения неясной становится граница между дилогией и переносами; с этой точки зрения трудно принять следующую трактовку: «...дилогия - это модель двусмысленности, в которой двусмысленность создается путем постановки многозначных слов или омонимов в такой контекст, где они могут пониматься несколькими способами одновременно»: Как-то странно получается. Надувают нас, а лопаются банки (Комсомольская правда. 2010. № 46) [15. C. 93]. Мы видим здесь замкнутую (а значит, однозначную) развернутую метафору (Надувают нас, алопаются БАНКИ).

Рассмотренному пониманию тождества формы как основы нарочитой двусмысленности могут быть поставлены в соответствие различные виды синтаксически обусловленной неоднозначности, ср.:

(37) - Свочм ПРЕДЛОЖЕНИЕМ вы осКорбЛЯРТ мое ПРАВИТЕЛЬСТВО! воскликнул сеньор Эспирисион, с негодованием и вставая с места.

\footnotetext{
1 Это терминологическое решение было принято в работе: [87. С. 257].
} 
- Тогда, - сказал мистер Франзони угрожающим тоном, - мы переменим его.

Предложение не подверглось никаким переменам. Неужели мистер Франзони говорил о перемене правительства? [О’Генри. Короли и капуста (1904), пер. К. Чуковского].

Ср. речевые смыслы (варианты прономинальной референции): оно ‘предложение' $\left(\mathrm{A}_{1}\right)$ и оно 'правительство' $\left(\mathrm{A}_{2}\right)$. Частным типом синтаксически обусловленной неоднозначности следует считать синтаксическую омонимию - случай, когда синтаксической единице (словосочетанию, предложению) можно приписать «две разные синтаксические структуры» [88. C. 176], например « $\mathrm{N}_{1}-\mathrm{V}_{\mathrm{f}}-\mathrm{N}_{4} »\left(\mathrm{~A}_{1}\right)$ и « $\mathrm{N}_{4}-\mathrm{V}_{\mathrm{f}}-\mathrm{N}_{1} »\left(\mathrm{~A}_{2}\right)$ :

(38) Тень отбрасывает предмет. // Тень отбрасывает людей. // Снопь темного света с асфальта // отбрасывают ноги, белую юбку, // наглье губы [А. Вознесенский. Тень отбрасывает предмет (1990)].

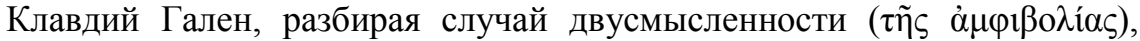
принадлежащий «речевой омонимии ( $\tau \tilde{\eta} \varsigma \dot{\varepsilon} v ~ \lambda o ́ \gamma \omega \dot{\alpha} \mu \omega v v \mu i ́ \alpha \varsigma) »$, которая

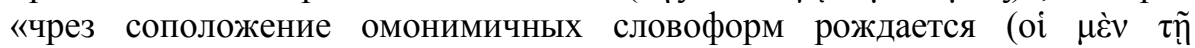

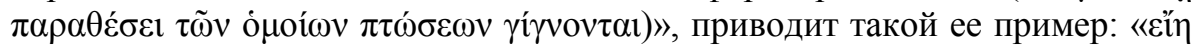

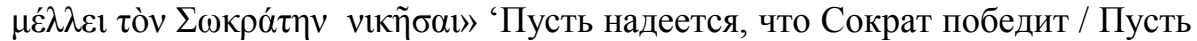
надеется Сократа победить’ [8. Р. 597 / De soph. IV]. В Новое время этот вид двусмыслицы трактуется как АМФиБОлия, в более узком смысле данного термина.

\section{3. Частичное тождество формы как основа двусмысленности.}

Намек на основе частичного тождества формы речевых единиц, т.е. их близкозвучия, известен как ФОНЕТИЧЕСКАЯ АЛЛЮЗИЯ. Предметом такой аллюзии бывает табуированное понятие: «...biser = baiser (verbe): allusion phonétique appliquée à un sens obscène» "biser " перекрашивать" = baiser (целовать): фонетическая аллюзия, примененная к обсценному смыслу’ [89. Р. 470], ср. также тьма тараканов и Тмутаракань:

(39) А долго ли прикажешь мне, // Платя в избе терпенью дани, // Истории тьму-таракани // Учиться по твоей стене? [П.А. Вяземский. Станция (1825)].

Фонетическая аллюзия используется и как фигура эзопова языка. Так, в следующем тексте «...предмет, о котором идет речь, не назван. Но слово тюрьма ясно ощутимо благодаря его фонетическим подобиям (кутерьма, тьма)» [90. С. 272]:

(40) Подумаешь, как в Чердыни-голубе, // Где пахнет Обью и Тобол в раструбе, // В семивершковой я метался кутерьме! // Клевешущих козлов не досмотрел я драки: // Как петушок в прозрачной легкой тьме... [О. Мандельштам. Стансы (1935)].

Фонетическая аллюзия, с определенной степенью уверенности, опознается:

a) в парафразе устойчивого выражения, ср. в семье не без урода и:

(41) Как говорят в народе, в семье - не без Мавроди [Комсомольская правда (1994)]. 
б) при опоре на рифму:

(42) Говорит он с горем // Фрейлинам дворца: // «Вешают за морем // За два за ...!» [А.С. Пушкин. Брови царь нахмуря... (1825)].

Аристотель, рассматривая ПАРАГРАММЫ (греч. $\pi \alpha \rho \alpha ́ \gamma \rho \alpha \mu \mu \alpha<\pi \alpha \rho \grave{\alpha}$ $\left.\gamma \rho \alpha ́ \mu \mu \alpha^{1}\right)$ - «остроты чрез перестановку букв ( качестве примера приводит стих, концовка которого нарушает ожидание адресата:

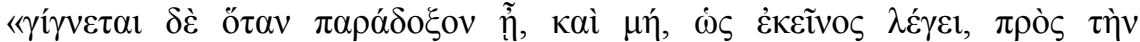

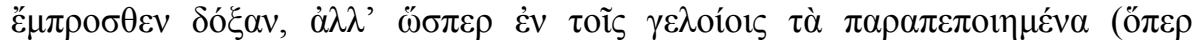

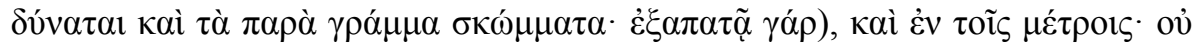

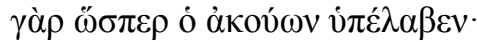

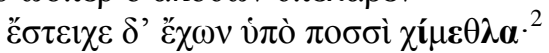

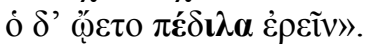

'Появляются такие парадоксы, смешные в силу своей неожиданности (которые возможны и чрез остроумно обманную перестановку букв), например в следующем стихе, в <концовке> коего слышится не то, что ожидается:

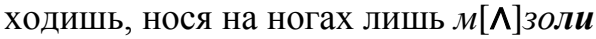

ожидается же, что c[^]ндали будет сказано' [82. P. 127 / Rhet. 1412a.25-30].

Пример замены, нарушающей рифменное и ритмическое ожидание, прозиметрический текст В.В. Воинова (1878-1938) «Мы» с подзаголовком «Прозаические стихи или стихотворная проза» (1913):

(43) $M$ мы - сыны равнины дикой, // Mbl - враги кривых путе еи, // Mbl идем к мечте великой // Под весельй свист... полевого ветра. /// Наше право за границей // Широко блюдут посльы, // Указуя нам десницей // Путь, куда идут... осторожные люди.

В таких текстах «...рифма с легкостью изобличает подделку» [85. С. 465]: nутей - плетей, посль - осльь. Как видим, и в этом случае, как и во всех рассмотренных нами выше, двусмысленность предполагает подразумевание единицы $\mathrm{A}_{2}$ под единицей $\mathrm{A}_{1}$, в связи с чем нельзя не отметить возможность синонимического применения терминов subintellectio 'подразумевание' и ambiguitas 'двусмысленность' в средневековой латиноязычной филологии: «subintellectio vel ambiguitas verborum» [92. Р. 286].

\section{Заключение}

1. ДВУСмЫСЛЕНнОСТь целесообразно понимать как подразумевание единицы $A_{2}\left(A_{3}, \ldots\right)$ под речевой единицей $A_{1}$ адресантом [1] при невозможности выбора между $\mathbf{A}_{1}$ и $\mathbf{A}_{2}\left(\mathbf{A}_{3}, \ldots\right)$ для адресата [2] ввиду дефектности контекста [3]. Идентификатор [1], а также конкретизаторы [2] и [3] исключают практикуемое в научной литературе отнесение к сфере

\footnotetext{
${ }^{1}$ Подробнее о параграмме как замене по близкозвучию, вступающей «в конфликт с привычным и ожидаемым (ultra solitum et justum)», см. обзор: [91. Стб. 3054].

2 Букв. 'язвы, болячки'.
} 
двусмысленной речи таких средств, как: 1) перенос, поддержанный опорным контекстом, в частности замкнутая метафора; 2) антанаклаза; 3) зевгма; 4) буквализация и др.

2. Помимо дефектности контекста условием речевой реализации категории двусмысленности является ассоциативная связь между $\mathrm{A}_{1}$ и $\mathrm{A}_{2}$ $\left(\mathrm{A}_{3}, \ldots\right)$. По характеру такой связи фигуры двусмысленной речи поддаются подразделению на следующие три разряда:

2.1. Фигуры, основанные на отношениях СЕМАНТИЧЕСКОЙ ПРОИЗВОДНОсти: 1) таксономические переносы, в том числе перенос с вида на вид, типом которого следует считать антифразис (как перенос с вида на противоположный вид), в частности хариентизм (включая элевацию и апофазию), астеизм и эпитроп; 2) метонимия, в частности металепсис (обозначение одной ситуации через другую, связанную с ней) и синекдоха; 3) незамкнутая метафора (т.е. метафора с отсутствующим ключевым словом), в частности аллегория и энигма («темная», т.е. используемая без пояснения, аллегория).

2.1.1. Значимыми параметрами для определения аллегории как вида метафоры являются: 1) количественный; 2) контекстуальный; 3) функциональный. С учетом данных трех параметров аллегория, в узком смысле данного термина, может быть определена как развернутая (количественный параметр) незамкнутая (контекстуальный параметр) метафора, используемая в целях разъяснения, в частности наставления (функциональный параметр). Ближайшим родовым понятием (genus proximum) для аллегории следует считать метафору ex simili, конкретизаторами (differentia) - замкнутый характер такой метафоры (a), ее развернутость (б) и направленность на пояснение (в). Восходящее к Античности типовое понимание аллегории как развернутой метафоры не дает возможности развести метафору замкнутую и незамкнутую, а потому нецелесообpазно. Метафора может быть либо замкнутой, либо незамкнутой, tertium non datur; с этой точки зрения не представляется оправданным применение понятия «неполной», или «смешанной», аллегории. Понятие метафоры in genere совпадает с понятием переноса, а потому в настоящее время иррелевантно, хотя и сохраняется в таких терминах, как буквализация метафоры, вынужденная метафора (лат. translatio / metaphora inopiae causa) 'катахреза'.

2.2. Фигуры, основанные на отношениях ПОЛноГО тОжДЕСТВА ФОРМЫ речевых единиц. Языковой основой таких фигур являются:

2.2.1. Омонимы различных типов, включая основанные на сдвиге.

2.2.2. Полисеманты, ЛСВ которых не связаны отношениями семантической производности, поскольку: а) восходят к одной производящей единице; б) связь через отношения семантической производности между такими ЛСВ утрачена либо существенно ослаблена и большинством носителей языка уже не ощущается. При сохранении между ЛСВ ощутимых отношений семантической производности следует говорить не о полисемии как основе двусмысленности, а о переносах (см. п. 2.1). 
2.2.3. Под дилогией целесообразно понимать прием с языковой основой (2.2).

2.2.4. В случае (2.2) выбор при интерпретации происходит между единицей $\mathrm{A}_{1}$ и единицей $\mathrm{A}_{2}$, при этом $\mathrm{A}_{1}$ и $\mathrm{A}_{2}$ не связаны отношениями семантической производности. Данному условию отвечает амфиболия - синтаксическая неоднозначность, в частности синтаксическая омонимия.

2.3. Фигуры, основанные на отношениях НЕПОЛНОГО тОЖДЕСТВА ФОРмы речевых единиц: фонетическая аллюзия, в частности параграмма.

3. Языковой основой фигур двусмысленной речи являются ассоциации: 1) деривационные (случаи 2.1 и 2.2.2a); 2) по равнозвучию (случай 2.2.1); 3 ) по близкозвучию либо созвучию (случай 2.3); случай (2.2.2б) расположен на шкале между полюсами, представленными типами (2.1) и (2.2.1).

\section{Лuтература}

1. Зализняк Анна А. Многозначность в языке и способы ее представления. М. : Языки славянской культуры, 2006. 673 с.

2. Казаков С.Э. Контекстуальная многозначность в пьесе Э. Олби «Крошка Алиса» // Экспрессивность текста и перевод / ред. Р.Э. Кульшарипова. Казань, 1991. С. 66-72.

3. Стернин И. А., Саломатина М. С. Семантический анализ слова в контексте. 2-е изд. Москва ; Берлин : Директ-Медиа, 2015. 202 с.

4. Кантылева Н.Г. Дефиниционная и контекстуальная многозначность термина «номенклатура» // Вестник Тюменского государственного университета. Гуманитарные исследования. 2015. Т. 1, № 4. С. 83-92.

5. Suidae lexicon. Graece et Latine. Tomi prioris pars prior (A-E). Halis et Brunsvigae : Sumtibus Schwetschkiorum, 1853. 744 p.

6. Schleusner J.F. Novum lexicon graeco-latinum in novum Testamentum. Ed. 5. Glasguae : Excudebant A. et J. Duncan, Academiae typographi, 1817. Vol. 1. 969 p.

7. Hervey G.W. A system of Christian rhetoric. N.Y. : Harper \& brothers, 1873. 632 p.

8. Galeni De sophismatis seu captionibus penes dictionem // Claudii Galeni Opera omnia / ed. by C.G. Kühn. Lipsiae : Prostat in officina libraria C. Cnoblochii, 1827. T. 14. P. 582598.

9. Словарь современного русского литературного языка / ред. К.С. Горбачевич. 2-е изд. М. : Рус. яз., 1993. Т. 4. 576 с.

10. Empson W. Seven types of ambiguity. N.Y. : New Directions, 1966 [1930]. 256 p.

11. Ossa-Richardson A. A history of ambiguity. Princeton ; Oxford : Princeton Univ. Press, 2019. 488 p.

12. Black M. The radical ambiguity of a poem // Synthese. 1984. Vol. 59, № 1. P. 89-107.

13. Attridge D. Peculiar language. London; New York : Routledge, 2005 [1988]. 280 p.

14. Beaty J., Matchett W.H. Poetry from statement to meaning. N.Y. : Oxford Univ. Press, 1965. $353 \mathrm{p}$.

15. Южанникова М.А. Феномен двусмысленности как основание стилистических приемов в современном русском языке : дис. ... канд. филол. наук. Красноярск, 2015. $208 \mathrm{c}$.

16. C. Chirii Fortunatiani Artis rhetoricae libri III // Rhetores Latini minores / ed. by K. Halm. Lipsiae : In aedibus B.G. Teubneri, 1863. P. 79-134.

17. M. Fabii Quintiliani Institutionis oratoriae libri duodecim. Lipsiae : Sumptibus et typis B.G. Teubneri, 1854. Vol. 2. 317 p.

18. Black M. Perplexities. Rational choice, the prisoner's dilemma, metaphor, poetic ambiguity, and other puzzles. Ithaca ; London : Cornell Univ. Press, 1990. 224 p.

19. Walton D. Fallacies arising from ambiguity. Dordrecht : Springer, 1996. 293 p. 
20. Dupriez B. A dictionary of literary devices: gradus, A-Z / transl. A. W. Halsall. 2nd edn. Toronto ; Buffalo : Univ. of Toronto Press, 1991 [1984].

21. Chamberlin J. Medieval arts doctrines on ambiguity and their places in Langland's Poetics. Montreal et al. : McGill-Queen's Univ. Press, 2000. 176 p.

22. Keller S.D. The development of Shakespeare's rhetoric. A study of nine plays. Tübingen : Franke Verlag, 2009. 310 p.

23. Ахманова О.С. Словарь лингвистических терминов. 2-е изд. М. : Эдиториал УРCC, 2004 [1969]. $571 \mathrm{c}$.

24. Pompeii Commentum Artis Donati // Grammatici latini / ed. by H. Keil. Lipsiae : In aedibus B. G. Teubneri, 1868. Vol. V. P. 81-312.

25. Diomedis Grammatici Opus. Lipsiae : I. Bervualdus excudebat, 1542. 208 p.

26. Wimsatt W.K. The verbal icon: studies in the meaning of poetry. Lexington : Univ. Press of Kentucky, 1982 [1954]. 299 p.

27. Lanham R.A. Analyzing prose. 2nd edn. London; New York : Continuum, 2003 [1983]. $244 \mathrm{p}$.

28. Lausberg $H$. Handbook of literary rhetoric. $3^{\text {rd }}$ edn. Leiden et al. : Brill, 1998 [1960]. $921 \mathrm{p}$.

29. Flavii Sosipatri Charisii Artis grammaticae libri V // Grammatici Latini / ed. by H. Keil. Lipsiae : In aedibus B.G. Teubneri, 1857. Vol. 1. P. 1-296.

30. Видлак C. Проблема эвфемизма на фоне теории языкового поля // Этимология / ред. О.Н. Трубачев. М., 1967. С. 267-285.

31. Giertz I. Semantic relations in the phenomenon of syllepsis. München : GRIN Verlag, 2007. $56 \mathrm{p}$.

32. Loney A.C. Grammatical and ethical ambiguities in Alcman 1.34-39 // Classical philology. 2011. Vol. 106, № 4. P. 343-349.

33. Stewart $G$. The deed of reading. Ithaca ; London : Cornell Univ. Press, 2015. 272 p.

34. Bergson H. Laughter. An essay on the meaning of the comic/transl. C. Brereton \& F. Rothwell. N.Y. : Dover Publications, 2005 [1900]. 112 p.

35. Olson K.M. Ambiguity // Encyclopedia of Rhetoric / ed. by Th. O. Sloane. N.Y.: Oxford Univ. Press, 2001. P. 21-25.

36. Фролова O.Е. Двусмысленность и ее разновидности // Вопросы культуры речи / ред. А.Д. Шмелев. М., 2012. Вып. 11. С. 263-273.

37. Сергеева Ю.М. К вопросу о субъективном факторе смысловой вариативности дискурса // Известия Южного федерального университета. Филологические науки. 2018. № 1. C. 79-87.

38. Москвин В. П. О типологии семантических переносов // Известия Российской академии наук. Серия лит. и яз. 2016. Т. 75, № 3. С. 5-18.

39. Bain A. English composition and rhetoric. N.Y. : Appleton \& Co, 1867. 343 p.

40. Blank A. Words and concepts in time: towards diachronic cognitive onomasiology // Words in time: diachronic semantics from different points of view / eds. by R. Eckardt, K. von Heusinger \& Ch. Schwarze. Berlin : Mouton de Gruyter, 2003. P. 37-65.

41. Жельвис В.И. Инвективы в парадигме средств фатического общения // Жанры речи / ред. В.В. Дементьев. Саратов, 1997. Вып. 1. С. 137-144.

42. Probi Donati Servii. De arte grammatica // Grammatici Latini / ed. by H. Keil. Lipsiae : In aedibus B.G. Teubneri, 1864. Vol. IV. P. 353-402.

43. Westheimer B. Collectanea troporum, Sacrae Scripturae candidatis utilißima. Argentorati : Albrecht, 1535. $492 \mathrm{p}$.

44. Tiberius Rhetor De schematibus apud Demosthenem // Rhetores selecti / ed. by Th. Gale. Oxonii : E Theatro Sheldoniano, 1676. P. 178-197.

45. Iulii Rufiniani. De figuris sententiarum et elocutionis liber // Rhetores latini minores / ed. by H. Keil. Lipsiae : In aedibus B.G. Teubneri, 1863. P. 38-62.

46. Aquilae Romani. De figuris sententiarum et elocutionis liber // P. Rutilii Lupi De figuris sententiarum et elocutionis libri duo item Aquilae Romani et Iulii Rufiniani de eodem 
argumento libri / eds. by D. Ruhnken \& C. Frotscher. Lipsiae : Gust. Schaarschmidt, 1831. P. 184-223.

47. Fontanier P. Les figures du discours. Paris : Flammarion, 1968 [1827]. 505 p.

48. Valla L. Dialectical disputations. Cambridge ; London : Harvard Univ. Press, 2012 [1439]. Vol. I. 397 p.

49. Осокина Н.Ю., Дектерев С.Б. Интенциональный семантический сдвиг градуальность $\rightarrow$ неградуальность как источник скрытых смыслов в произведениях современных англоязычных авторов // Вестник Томского государственного университета. Филология. 2019. № 57. С. 124-136.

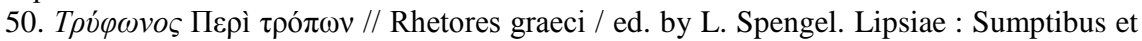
typis B. G. Teubneri, 1856. Vol. 3. P. 189-206.

51. Загоровская О.В., Соколова Н.К. Индивидуально-авторское словоупотребление А. Блока и традиционная поэтическая норма // Вопросы стилистики / ред. О.Б. Сиротинина. Саратов, 1976. Вып. 11. С. 199-127.

52. Tuggy D. Ambiguity, polysemy, and vagueness // Cognitive linguistics / ed. by D. Geeraerts. The Hague, 2006. P. 167-184.

53. Huret J. Enquête sur l'évolution littéraire. Paris : Bibliothèque Charpentier, 1891. $451 \mathrm{p}$.

54. Marni A. Allegory in the French heroic poem of the seventeenth century. 2nd edn. N.Y. : Haskel House, 1971 [1936]. 211 p.

55. Snodgrass $K$. The parable of the wicked tenants. An inquiry into parable interpretation. Tübingen : Mohr Siebeck, 1983. $150 \mathrm{p}$.

56. Wilson D. Allegories of love: Cervantes's «Persiles and Sigismunda». Princeton : Princeton Univ. Press, 1991. 282 p.

57. Bloomfield M.W. A grammatical approach to personification allegory // Modern philology. 1963. Vol. 60, № 3. P. 161-171.

58. Brown J.K. The persistence of allegory. Drama and neoclassicism from Shakespeare to Wagner. Philadelphia : Univ. of Pennsylvania Press, 2007. 304 p.

59. Tambling J. Allegory. Abington ; New York : Routledge, 2010. 192 p.

60. Lewis C.S. The allegory of love. A study in Medieval tradition. N.Y. : Oxford Univ. Press, 1958 [1936]. 378 p.

61. M. Tullii Ciceronis. Orator // M. Tullii Ciceronis. Opera omnia / ed. by Ch.G. Schütz. Augustae Taurinorum, 1824. Vol. 3. P. 187-312.

62. Teskey G. Allegory and violence. Ithaca ; London : Cornell Univ. Press, 1996. 195 p.

63. Левин Ю.И. Структура русской метафоры // Ученые записки Тарт. гос. ун-та. Вып. 181: Труды по знаковым системам. Т. 2 / ред. Ю.М. Лотман. Тарту, 1965. С. 293299.

64. Aristotelis. Ars rhetorica cum adnotatione Leonardi Spengel. Accedit vetusta trabslatio Latuna. Lipsiae : In aedibus B. G. Teubneri, 1867. Vol. 1. 356 p.

65. Потебня А.А. Теоретическая поэтика. М. : Высш. шк., 1990 [1905]. 344 с.

66. Gerardi Ioannis Vossii. Rhetorices contractae, sive Partitionum oratoriarum libri quinque. Matriti : Apud A. Sancham, 1781. 726 p.

67. Aaron D.H. Biblical ambiguities. Metaphor, semantics, and divine imagery. Boston ; Leiden : Brill, 2002. 221 p.

68. Landheer $R$. La métaphore, une question de vie ou de mort? // Figures du discours et ambiguïté / éd. by J.-C. Arfouilloux et al. Besançon, 2002. P. 25-39.

69. Luxon Th.H. Literal Figures. Puritan allegory and the Reformation crisis in representation. Chicago ; London : Univ. of Chicago Press, 1995. 256 p.

70. Swaim K.M. Pilgrim's progress, puritan progress. Discourses and contexts. Urbana; Chicago : Univ. of Illinois Press, 1993. 368 p.

71. Lamberton $R$. Homer the theologian: Neoplatonist allegorical reading and the growth of the epic tradition. Berkeley : Univ. of California Press, 1989. 384 p. 
72. Machosky B. Structures of appearing. Allegory and the work of literature. N.Y.: Fordham Univ. Press, 2013. 259 p.

73. Frye N. Anatomy of criticism. Toronto : Univ. of Toronto Press, 2006 [1957]. 450 p.

74. Fletcher A. Allegory. The theory of a symbolic mode. N.Y. : Cornell Univ. Press, 1964. $475 \mathrm{p}$.

75. Bedae Venerabilis. De schematibus et tropis // Rhetores latini minores / ed. by K. Halm. Lipsiae, 1863. P. 607-618.

76. Isidori Hispalensis episcopi. Etymologiarum. Lipsiae : Sumptibus B.G. Teubneri et F. Claudii, 1833. 702 p.

77. M.T. Ciceronis, ut ferunt, Rhetoricorum ad Herennium libri quattuor: ejusdem De inventione rhetorica libri duo. Lipsiae : Sumtibus L.C. Hinrichsii, 1828. 705 p.

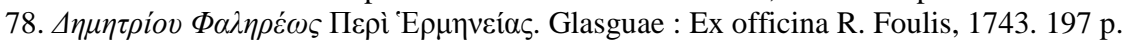

79. Comenii J.A. In januam linguae Latinae // J.A. Comenii. Opera didactica omnia. Amsterdami, 1657. P. 476-591.

80. Aristotelis. De arte poetica. Oxford ; London : J. Parker \& CO, 1879. 173 p.

81. Obbink D. Early Greek allegory // The Cambridge companion to allegory / eds. by R. Copeland, P.T. Struck. Cambridge; New York : Cambridge Univ. Press, 2011. P. 15-25.

82. Aristotelis. De sophisticis elenchis // Aristotelis. Opera omnia: Graece et latine. Parisiis: Editore A. Firmin-Didot, 1848. Vol. 1. P. 276-309.

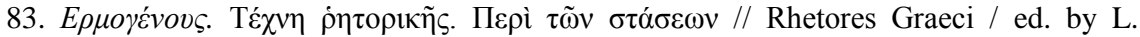
Spengel. Lipsiae, 1854. Vol. 2. P. 133-175.

84. Шмелев Д.Н. Омонимия // Лингвистический энциклопедический словарь / ред. В.Н. Ярцева. М., 1990. С. 344-345.

85. Санников B.3. Русский язык в зеркале языковой игры. М. : Языки славянской культуры, 1999. 544 с.

86. Кустова Г.И. Типы производных значений и механизмы языкового расширения. М. : Языки славянской культуры, 2004. 472 с.

87. Москвин В.П. Стилистика русского языка. Теоретический курс. Ростов н/Д : Феникс, 2006 [2000]. $630 \mathrm{c.}$

88. Апресян Ю.Д. Избранные труды. Т. 1: Лексическая семантика. Синонимические средства языка [1974]. 2-е изд., испр. и доп. М. : Языки славянской культуры, 1995. $473 \mathrm{c}$.

89. Lombroso C. L'homme criminel, criminel-né, fou moral, épileptique. Étude anthropologique et médico-légale / trad. G. Régnier, A. Bournet. Éd. 4. Paris : F. Alcan, 1887. $682 \mathrm{p}$.

90. Хализев B.E. Теория литературы. М. : Высш. шк., 1999. 330 с.

91. Thesaurus Graecae linguae ab H. Stephano. Editio nova auctior et emendatior. Londini : In Aedibus Valpianis, 1821-1822. Vol. 3. 1237 p.

92. Theophili Raynaudi Sosietatis iesu theologi, Polemica. Tomus decimus-octavus. Lugduni : Sumpt. Horatii Boissat, \& Georgii Remeus, 1665. 540 p.

\section{The Ambiguity of Speech: A Stylistic Aspect}

Vestnik Tomskogo gosudarstvennogo universiteta. Filologiya - Tomsk State University Journal of Philology. 2021. 70. 90-120. DOI: 10.17223/19986645/70/6

Vasily P. Moskvin, Volgograd State Socio-Pedagogical University (Volgograd, Russian Federation). E-mail: vasmoskvin@yandex.ru

Keywords: ambiguity, figure of speech, taxonomic transfer, metonymy, open metaphor, allegory, dilogy, phonetic allusion.

The aim of this research is to clarify the concept of ambiguity and, accordingly, the set of ambiguous speech figures, interpretations of which in the literature demonstrate a significant diversity of opinions. The research material is primarily literary, in particular, poetic, speech, which is characterized by an acute stylistic effect achieved by functionally relevant 
violations of communicative norms - the requirement of speech unambiguity in our case; the sample size was more than 300 units. The study showed that: 1) ambiguity should be considered as the implication of speech unit $A_{2}\left(A_{3}, \ldots\right)$ under unit $A_{1}$ by the addresser when it is impossible for the addressee to make an unambiguous choice between $A_{1}$ and $A_{2}$ $\left(\mathrm{A}_{3}, \ldots\right)$ due to the defective context; accordingly, in addition to descriptive and transformational methods, the study used contextual and motivational analysis; 2) the condition for implementing ambiguity in speech is the presence of an associative relationship between $\mathrm{A}_{1}$ and $A_{2}\left(A_{3}, \ldots\right)$. According to the nature of this relationship, the figures of ambiguous speech can be divided into three rows. 1 . Row 1 is based on the relations of semantic derivation: a) taxonomic transfers; b) metonymy, in particular metalepsis and synecdoche; c) open metaphor, including allegory and enigma. The closest generic concept for allegory appears to be the ex simili metaphor, the concretizers are the open nature of this metaphor, its expansion and focus on explanation. The typical (going back to the Antiquity) understanding of allegory as an expanded metaphor does not make it possible to distinguish closed and open metaphors; therefore, it is inadvisable. A metaphor can be either closed (i.e., unambiguous) or open, tertium non datur; from this point of view, the use of the concept of "incomplete" allegory is unreasonable. 2. Row 2 is based on the relations of the complete identity of the form (dilogy; in particular, amphiboly). The language basis of these figures are: 1) homonyms; 2) polysemants whose lexical-semantic variants (LSVs) are not linked with semantic derivation relations, since: a) LSVs go back to one producing unit (thus being coderivatives); b) the connection through semantic derivation relations between LSVs is lost or weakened, and most speakers of the language do not longer feel it. If there is a tangible relation of semantic derivation between LSVs, the basis of ambiguity is not polysemy, but transfers (See point 1). 3. Row 3 is based on relations of incomplete identity of the form (phonetic allusion; in particular, paragram). Thus, the linguistic basis of figures of ambiguous speech are associations: 1) derivational (cases 1 and 2.2a); 2) by the same sounding (case 2.1);3) by close-sounding or consonance of nominative units (case 3 ); case (2.2 b) is located on the scale between the poles represented by types (1) and (2.1).

\section{References}

1. Zaliznyak, A.A. (2006) Mnogoznachnost'v yazyke $i$ sposoby ee predstavleniya [Polysemy in the language and ways of its representation]. Moscow: Yazyki slavyanskoy kul'tury.

2. Kazakov, S.E. (1991) Kontekstual'naya mnogoznachnost' v p'ese E. Olbi “Kroshka Alisa" [Contextual ambiguity in E. Albee's play "Little Alice"]. In: Kulsharipova, R.E. (ed.) Ekspressivnost' teksta i perevod [Text expressiveness and translation]. Kazan: Kazan State University. pp. 66-72.

3. Sternin, I.A. \& Salomatina, M.S. (2015) Semanticheskiy analiz slova v kontekste [Semantic analysis of a word in context]. 2nd ed. Moscow; Berlin: Direkt-Media.

4. Kantysheva, N.G. (2015) Definitional and contextual ambiguity of the term "nomenclature". Vestnik Tyumenskogo gosudarstvennogo universiteta. Gumanitarnye issledovaniya. 1 (4). pp. 83-92. (In Russian).

5. Suidas. (1853) Suidae Lexicon. Graece et Latine. Tomi prioris pars prior (A-E). Halis et Brunsvigae: Sumtibus Schwetschkiorum.

6. Schleusner, J.F. (1817) Novum lexicon graeco-latinum in novum Testamentum. Ed. 5. Vol. 1. Glasguae: Excudebant A. et J. Duncan, Academiae typographi.

7. Hervey, G.W. (1873) A system of Christian rhetoric. N.Y.: Harper \& brothers.

8. Galenus, C. (1827) De sophismatis seu captionibus penes dictionem. In: Kühn, C.G. (ed.) Claudii Galeni Opera omnia. 14. Lipsiae: Prostat in officina libraria C. Cnoblochii. pp. 582-598. 
9. Gorbachevich, K.S. (ed.) (1993) Slovar'sovremennogo russkogo literaturnogo yazyka [Dictionary of modern Russian literary language]. 2nd ed. Vol. 4. Moscow: Rus. yaz.

10. Empson, W. (1966/1930) Seven types of ambiguity. N.Y.: New Directions.

11. Ossa-Richardson, A. (2019) A history of ambiguity. Princeton; Oxford: Princeton Univ. Press.

12. Black, M. (1984) The radical ambiguity of a poem. Synthese. 59 (1). pp. 89-107.

13. Attridge, D. (2005) Peculiar language. 2nd ed. London; New York: Routledge.

14. Beaty, J. \& Matchett, W.H. (1965) Poetry from statement to meaning. N.Y.: Oxford Univ. Press.

15. Yuzhannikova, M.A. (2015) Fenomen dvusmyslennosti kak osnovanie stilisticheskikh priemov $v$ sovremennom russkom yazyke [The phenomenon of ambiguity as the basis of stylistic techniques in the modern Russian language]. Philology Cand. Diss. Krasnoyarsk.

16. Fortunatiani, C.C. (1863) Artis rhetoricae libri III In: Halm, K. (ed.) Rhetores Latini minores. Lipsiae: In aedibus B.G. Teubneri. pp. 79-134.

17. Quintiliani, M.F. (1854) Institutionis oratoriae libri duodecim. Vol. 2. Lipsiae: Sumptibus et typis B.G. Teubneri.

18. Black, M. (1990) Perplexities. Rational choice, the prisoner's dilemma, metaphor, poetic ambiguity, and other puzzles. Ithaca; London: Cornell Univ. Press.

19. Walton, D. (1996) Fallacies arising from ambiguity. Dordrecht: Springer.

20. Dupriez, B. (1991) A dictionary of literary devices: gradus, A-Z. Transl. A. W. Halsall. 2nd ed. Toronto; Buffalo: Univ. of Toronto Press.

21. Chamberlin, J. (2000) Medieval arts doctrines on ambiguity and their places in Langland's Poetics. Montreal et al.: McGill-Queen's Univ. Press.

22. Keller, S.D. (2009) The development of Shakespeare's rhetoric. A study of nine plays. Tübingen: Franke Verlag.

23. Akhmanova, O.S. (2004) Slovar' lingvisticheskikh terminov [Dictionary of linguistic terms]. 2nd ed. Moscow: Editorial URSS.

24. Pompeius. (1868) Pompeii Commentum Artis Donati. In: Keil, H. (ed.) Grammatici latini. Vol. V. Lipsiae: In aedibus B. G. Teubneri. pp. 81-312.

25. Diomedes. (1542) Grammatici Opus. Lipsiae: I. Bervualdus excudebat.

26. Wimsatt, W.K. (1982) The verbal icon: studies in the meaning of poetry. 2nd ed. Lexington: Univ. Press of Kentucky.

27. Lanham, R.A. (2003) Analyzing prose. 2nd ed. London; New York: Continuum.

28. Lausberg, H. (1998) Handbook of literary rhetoric. 3rd ed. Leiden et al.: Brill.

29. Flavius, S.Ch. (1857) Artis grammaticae libri V. In: Keil, H. (ed.) Grammatici Latini. I. Lipsiae: In aedibus B. G. Teubneri. pp. 1-296.

30. Vidlak, S. (1967) Problema evfemizma na fone teorii yazykovogo polya [The problem of euphemism against the background of the theory of the language field]. In: Trubachev, O.N. (ed.) Etimologiya [Etymology]. Moscow: Nauka. pp. 267-285. Verlag.

31. Giertz, I. (2007) Semantic relations in the phenomenon of syllepsis. München: GRIN

32. Loney, A.C. (2011) Grammatical and ethical ambiguities in Alcman 1.34-39. Classical Philology. 106 (4). pp. 343-349.

33. Stewart, G. (2015) The deed of reading. Ithaca; London: Cornell Univ. Press.

34. Bergson, H. (2005/1900) Laughter. An essay on the meaning of the comic. Transl. C. Brereton \& F. Rothwell. N.Y.: Dover Publications.

35. Olson, K.M. (2001) Ambiguity. In: Sloane, Th.O. (ed.) Encyclopedia of Rhetoric. N.Y.: Oxford Univ. Press. pp. 21-25.

36. Frolova, O.E. (2012) Dvusmyslennost' i ee raznovidnosti [Ambiguity and its varieties]. In: Shmelev, A.D. (ed.) Voprosy kul'tury rechi [Issues of the culture of speech]. Vol. 11. Moscow: Yazyki slavyanskoi kul’tury. pp. 263-273. 
37. Sergeeva, Yu.M. (2018) Personal Factor of Semantic Variability in Discourse. Izvestiya Yuzhnogo federal'nogo universiteta. Filologicheskie nauki - Proceedings of Southern Federal University. Philology. 1. pp. 79-87. (In Russian).

38. Moskvin, V.P. (2016) O tipologii semanticheskikh perenosov [On the typology of semantic transfers]. Izvestiya Rossiyskoy akademii nauk. Seriya lit. i yaz.75 (3). pp. 5-18.

39. Bain, A. (1867) English composition and rhetoric. N.Y.: Appleton \& Co.

40. Blank, A. (2003) Words and concepts in time: towards diachronic cognitive onomasiology. In: Eckardt, R., von Heusinger, K. \& Schwarze, Ch. (eds) Words in time: diachronic semantics from different points of view. Berlin: Mouton de Gruyter. pp. 37-65.

41. Zhel'vis, V.I. (1997) Invektivy v paradigme sredstv faticheskogo obshcheniya [Invectives in the paradigm of fatic communication tools]. In: Dement'ev, V.V. (ed.) Zhanry rechi [Speech genres]. Vol. 1. Saratov: Kolledzh. pp. 137-144.

42. Probus, D.S. (1864) De arte grammatica. In: Keil, H. (ed.) Grammatici Latini. Vol. IV. Lipsiae: In aedibus B.G. Teubneri. pp. 353-402.

43. Westheimer, B. (1535) Collectanea troporum, Sacrae Scripturae candidatis utilißima. Argentorati: Albrecht.

44. Tiberius. (1676) De schematibus apud Demosthenem. In: Gale, Th. (ed.) Rhetores selecti. Oxonii: E Theatro Sheldoniano. pp. 178-197.

45. Rufinianus, I. (1863) De figuris sententiarum et elocutionis liber. In: Keil, H. (ed.) Rhetores latini minores. Lipsiae: In aedibus B.G. Teubneri. pp. 38-62.

46. Romanus, A. (1831) De figuris sententiarum et elocutionis liber. In: Ruhnken, D. \& Frotscher, C. (eds) P. Rutilii Lupi De figuris sententiarum et elocutionis libri duo item Aquilae Romani et Iulii Rufiniani de eodem argumento libri. Lipsiae: Gust. Schaarschmidt. pp. 184223.

47. Fontanier, P. (1968/1827) Les figures du discours. Paris: Flammarion.

48. Valla, L. (2012/1439) Dialectical disputations. Vol. I. Cambridge; London: Harvard Univ. Press.

49. Osokina, N.Yu. \& Dekterev, S.B. (2019) The Intentional Semantic Shift Gradable $\rightarrow$ Non-Gradable as a Means of Creating Ambiguity and Implication in a Literary Text. Vestnik Tomskogo gosudarstvennogo universiteta. Filologiya - Tomsk State University Journal of Philology. 57. pp. 124-136. (In Russian). DOI: 10.17223/19986645/57/7

50. Tryphon. (1856) De tropis. In: Spengel, L. (ed.) Rhetores graeci. Vol. 3. Lipsiae: Sumptibus et typis B. G. Teubneri. pp. 189-206.

51. Zagorovskaya, O.V. \& Sokolova, N.K. (1976) Individual'no-avtorskoe slovoupotreblenie A. Bloka i traditsionnaya poeticheskaya norma [Individual author's word usage of A. Blok and traditional poetic norm]. In Sirotinin, O.B. (ed.) Voprosy stilistiki [Issues of stylistics]. Vol. 11. Saratov: Saratov State University. pp. 199-127.

52. Tuggy, D. (2006) Ambiguity, polysemy, and vagueness. In: Geeraerts, D. (ed.) Cognitive linguistics. Basic Readings. The Hague. pp. 167-184.

53. Huret, J. (1891) Enquête sur l'évolution littéraire. Paris: Bibliothèque Charpentier.

54. Marni, A. (1971) Allegory in the French heroic poem of the seventeenth century. 2nd ed. N.Y.: Haskel House.

55. Snodgrass, K. (1983) The parable of the wicked tenants. An inquiry into parable interpretation. Tübingen: Mohr Siebeck.

56. Wilson, D. (1991) Allegories of love: Cervantes's "Persiles and Sigismunda". Princeton: Princeton Univ. Press.

57. Bloomfield, M.W. (1963) A grammatical approach to personification allegory. Modern Philology. 60 (3). pp. 161-171.

58. Brown, J.K. (2007) The persistence of allegory. Drama and neoclassicism from Shakespeare to Wagner. Philadelphia: Univ. of Pennsylvania Press.

59. Tambling, J. (2010) Allegory. Abington; New York: Routledge.

60. Lewis, C.S. (1958/1936) The allegory of love. A study in Medieval tradition. N.Y.: Oxford Univ. Press. 
61. Cicero, M. T. (1824) Orator. In: Schütz, Ch. G. (ed.) M. Tullii Ciceronis Opera omnia. Vol. 3. Augustae Taurinorum. pp. 187-312.

62. Teskey, G. (1996) Allegory and violence. Ithaca; London: Cornell Univ. Press.

63. Levin, Yu.I. (1965) Struktura russkoy metafory [Structure of the Russian metaphor]. Uchenye zapiski Tartuskogo gosudarstvennogo universiteta. 181 (2). pp. 293-299.

64. Aristoteles. (1867) Ars rhetorica cum adnotatione Leonardi Spengel. Accedit vetusta trabslatio Latuna. Vol. 1. Lipsiae: In aedibus B. G. Teubneri.

65. Potebnya, A.A. (1990) Teoreticheskaya poetika [Theoretical poetics]. Moscow: Vysshaya shkola.

66. Vossius, G.I. (1781) Rhetorices contractae, sive Partitionum oratoriarum libri quinque. Matriti: Apud A. Sancham.

67. Aaronm, D.H. (2002) Biblical ambiguities. Metaphor, semantics, and divine imagery. Boston \& Leiden: Brill.

68. Landheer, R. (2002) La métaphore, une question de vie ou de mort? In: Arfouilloux, J.-C. et al. (eds) Figures du discours et ambiguïté. Besançon. pp. 25-39.

69. Luxon, Th.H. (1995) Literal Figures. Puritan allegory and the Reformation crisis in representation. Chicago; London: Univ. of Chicago Press.

70. Swaim, K.M. (1993) Pilgrim's progress, puritan progress. Discourses and contexts. Urbana; Chicago: Univ. of Illinois Press.

71. Lamberton, R. (1989) Homer the theologian: Neoplatonist allegorical reading and the growth of the epic tradition. Berkeley: Univ. of California Press.

72. Machosky, B. (2013) Structures of appearing. Allegory and the work of literature. N.Y.: Fordham Univ. Press.

73. Frye, N. (2006/1957) Anatomy of criticism. Toronto: Univ. of Toronto Press.

74. Fletcher, A. (1964) Allegory. The theory of a symbolic mode. N.Y.: Cornell Univ. Press.

75. Bedae Venerabilis. (1863) De schematibus et tropis. In: Halm, K. (ed.) Rhetores latini minores. Lipsiae: In aedibus B. G. Teubneri. pp. 607-618.

76. Hispalensis, I. (1833) Etymologiarum. Lipsiae: Sumptibus B. G. Teubneri et F. Claudii.

77. Cicero, M. T. (1828) Rhetoricorum ad Herennium libri quattuor: ejusdem De inventione rhetorica libri duo. Lipsiae: Sumtibus L. C. Hinrichsii.

78. Phalereus, D. (1743) Peri Hermeneias. Glasguae: Ex officina R. Foulis.

79. Comenii, J.A. (1657) In januam linguae Latinae In: Geer, D.L. (ed.) J.A. Comenii Opera didactica omnia. Amsterdami: Excuderunt C. Cunradus, \& G. Rot. pp. 476-591.

80. Aristoteles. (1879) De arte poetica. Oxford; London: J. Parker \& CO.

81. Obbink, D. (2011) Early Greek allegory. In: Copeland, R. \& Struck, P.T. (eds) The Cambridge companion to allegory. Cambridge; New York: Cambridge Univ. Press. pp. 15-25.

82. Aristoteles. (1848) De sophisticis elenchis. In: Opera omnia: Graece et latine. Vol. 1. Parisiis: Editore A. Firmin-Didot. pp. 276-309.

83. Hermogenes. (1854) Art of Rhetoric. De statuum dicendi doctrina. In: Spengel, L. (ed.) Rhetores Graeci. Vol. 2. Lipsiae: In aedibus B. G. Teubneri. pp. 133-175.

84. Shmelev, D.N. (1990) Omonimiya [Homonymy]. In: Yartseva, V.N. (ed.) Lingvisticheskiy entsiklopedicheskiy slovar' [Linguistic encyclopedic dictionary]. Moscow: Sovetskaya entsiklopediya. pp. 344-345.

85. Sannikov, V.Z. (1999) Russkiy yazyk v zerkale yazykovoy igry [The Russian language in the mirror of the language game]. Moscow: Yazyki slavyanskoy kul'tury.

86. Kustova, G.I. (2004) Tipy proizvodnykh znacheniy $i$ mekhanizmy yazykovogo rasshireniya [The types of derivative meanings and mechanisms of language extension]. Moscow: Yazyki slavyanskoy kul'tury.

87. Moskvin, V.P. (2006/2002) Stilistika russkogo yazyka. Teoreticheskiy kurs [Stylistics of the Russian language. Theoretical course]. Rostov-on-Don: Feniks. 
88. Apresyan, Yu.D. (1995) Izbrannye trudy [Selected works]. 2nd ed. Vol. 1. Moscow: Yazyki slavyanskoy kul'tury.

89. Lombroso, C. (1887) L’homme criminel, criminel-né, fou moral, épileptique. Étude anthropologique et médico-légale. Trad. G. Régnier, A. Bournet. Éd. 4. Paris: F. Alcan.

90. Khalizev, V.E. (1999) Teoriya literatury [Theory of literature]. Moscow: Vysshaya shkola.

91. Stephanus, H. (1821-1822) Thesaurus Graecae linguae. Vol. 3. Londini: In Aedibus Valpianis.

92. Raynaud, Th. (1665) Polemica. Vol. 18. Lugduni: Sumpt. Horatii Boissat, \& Georgii Remeus. 